\title{
Masquerade: a novel secreted serine protease-like molecule is required for somatic muscle attachment in the Drosophila embryo
}

\author{
Bernadette Murugasu-Oei, ${ }^{1}$ Veronica Rodrigues, ${ }^{2}$ Xiaohang Yang, ${ }^{1}$ and William Chia ${ }^{1,3}$ \\ ${ }^{1}$ Institute of Molecular and Cell Biology, National University of Singapore, Singapore 0511, Republic of Singapore; \\ ${ }^{2}$ Molecular Biology Unit, Tata Institute of Fundamental Research, Bombay 400005, India
}

\begin{abstract}
Diverse developmental processes, such as neuronal growth cone migration and cell shape changes, are mediated by the interactions of cells with the extracellular matrix. We describe here a secreted molecule encoded by the Drosophila masquerade (mas) gene. Total loss of mas function causes defective muscle attachment. This mutant phenotype suggests that mas normally acts to stabilize cell-matrix interaction and represents a novel functional and limiting component in the adhesion process. mas encodes a 1047-amino-acid preproprotein that is further processed by proteolytic cleavage to generate two polypeptides. The carboxy-terminal polypeptide is highly similar to serine proteases and has an extracellular localization; however, it is unlikely to possess proteolytic activity, because the catalytic site serine has been substituted by a glycine residue. During embryonic development, the mas amino- and carboxy-terminal polypeptides are differentially localized. The mas carboxy-terminal polypeptide accumulates at all somatic muscle attachment sites, which corresponds well with the morphological defect seen in the mas mutants. Our findings demonstrate the involvement of an extracellular component in somatic muscle attachment. We propose that mas acts via its modified serine protease motif, either as a novel adhesion molecule and/or as a competitive antagonist of serine proteases, to stabilize muscle attachment.
\end{abstract}

[Key Words: Muscle attachment; serine protease; Drosophila; extracellular molecule; masquerade]

Received October 27, 1994; revised version accepted December 7, 1994.

The development of the Drosophila somatic musculature is a multistage process. After germ-band retraction, myoblasts fuse to form muscles and the differentiating structures make attachments at specific sites on the epidermis (Williams and Caveney 1980). By $13 \mathrm{hr}$ after egg laying, the formation of muscle pattern is complete and the muscles have established or are establishing muscle insertion points at characteristic locations on the epidermis (Bate 1990). The assembly of developing muscle insertions in insects involves the formation of adhesive junctions between the interdigitating processes of the epidermis and the muscle fibers (Lai-Fook 1967; Poodry 1980).

Members of the Drosophila integrin family (Leptin et al. 1987), named PS integrins, were first identified as antigens expressed in a position-specific manner in the wing imaginal disc (Wilcox et al. 1981; Brower et al. 1984). PS $1\left(\alpha_{\mathrm{ps} 1} \beta_{\mathrm{ps}}\right)$ and PS2 $\left(\alpha_{\mathrm{ps} 2} \beta_{\mathrm{ps}}\right)$ integrins are both heterodimers with identical $\beta$-subunits but different $\alpha$-subunits. The $\alpha_{\mathrm{ps} 2}$-subunit is encoded by the inflated (if) gene (Bogaert et al. 1987; Brower and Jaffe 1989; Brown et al. 1989; Wilcox et al. 1989; Brown 1994),

${ }^{3}$ Corresponding author. whereas the common $\beta_{\mathrm{ps}}$-subunit is encoded by I(1)myospheroid (mys) gene (MacKrell et al. 1988; Leptin et al. 1989). Defects seen in mys embryos (for reviews, see Brown 1993; Bunch and Brower 1993|, which fail to synthesize both PS1 and PS2, include the formation of myospheroid bodies caused when somatic muscles detach from the body wall and round up. Mutant if embryos show defects in embryonic somatic muscle attachment that are similar to (Brabant and Brower 1993) but less severe than those seen in mys embryos (Brown 1993, 1994). Ultrastructural studies indicate that there are matrix components in the junction between the apposing epidermal and muscle cells (Newman and Wright 1981). The differential localization of PS1 and PS2 on complementary sides of the epidermal-muscle junction and the differences in the severity of the phenotypes of the mutants lacking these molecules support the idea that they both bind to protein components of the extracellular matrix (ECM) to effect muscle attachment (Brown 1993, 1994).

In the developing embryo, the ECM affects cell differentiation and proliferation, provides an environment for cell migration, and serves as a substratum for guidance and adhesion (Bard 1990). Genes encoding several major 
classes of extracellular matrix (substrate) adhesion molecules (for review, see Fessler and Fessler 1989), as well as cell adhesion molecules (see Hortsch and Goodman 1991; Goodman and Doe 1993|, have been identified and characterized in Drosophila. These molecules show striking structural similarities to their mammalian counterparts, suggesting a conservation in function (Hynes 1992; Kreis and Vale 1993). However, with the notable exception of the integrins, the functional roles of most of the Drosophila ECM/cell adhesion molecules have not been defined precisely for want of an informative mutant phenotype. For example, null alleles of the gene encoding the substrate adhesion molecule laminin A (Garrison et al. 1991; Kusche-Gullberg 1992; Henchcliffe et al. 1993) exhibit no obvious embryonic morphological abnormalities. However, an array of defective adult structures was reported (Henchcliffe et al, 1993). It would seem, at least in the embryo, that the loss of function of substrate adhesion molecules like laminin $\mathrm{A}$, as well as many of the cell adhesion molecules, can be compensated in part by other components of the ECM or cell surface. Hence, it may be necessary to remove multiple components of the system to observe a phenotype.

Proteases can modulate the interactions of the cell surface with the extracellular environment either directly, for example, by localized and directional degradation of the ECM (e.g., Pollanen et al. 1988; Werb et al. 1989), or indirectly by activating signal transduction pathways (Vu et al. 1991) to effect, for example, the reorganization of cytoskeleton (Jalink and Moolenaar 1992) or neurite retraction (Suidan et al. 1992). The enzymatic activities of most proteases are regulated, being synthesized as inactive zymogens that only become enzymatically active following processing. Once activated, the domain of enzymatic activity can be further modulated by enzymatic inhibitors (see Hecht and Anderson 1992). The effects of the interplay of proteases (e.g., Gurwitz and Cunningham 1988; Dihanich et al. 1991) and their inhibitors (Gloor et al. 1986; Reinhard et al. 1988) have been proposed to play an important role in growth cone motility and in neurite outgrowth (Monard 1988; Suidan et al. 1992; Sumi et al. 1992). Mutations in the Drosophila Stubble-stubbloid $(S b$-sbd) gene, which encodes an apparent transmembrane protein with an extracellular serine protease domain, cause defects in cell shape and changes in the organization of microfilament bundles required for normal imaginal disc and bristle morphogenesis (Appel et al. 1993). Although the molecular substrates for the protease encoded by $S b$-sbd have not been elucidated, it seems likely that the molecular interactions (e.g., between receptors like integrins and protein components of the ECM) that have effects on cell shape and movement are regulated, at least in part, by the interplay between proteases and their inhibitors.

Here, we describe the characterization of the gene masquerade (mas) that encodes a secreted molecule with striking similarities to serine proteases; however, it is unlikely to possess proteolytic activity, because the essential catalytic serine residue has not been conserved in mas. Our results indicate that mas is processed to generate two polypeptides that are differentially localized. The carboxy-terminal "modified serine protease domain" accumulates at all embryonic somatic muscle attachment sites coinciding with the defects seen in animals lacking mas function. Total loss of function of mas is embryonic lethal and results in the formation of myospheroid bodies and detached somatic muscles. This phenotype points to a role for mas as an extracellular component required for the stabilization of somatic muscle attachment. We discuss possible mechanisms by which mas might act in this process.

\section{Results}

Identification, cloning, and analysis of the mas gene and three mutant alleles

mas was identified originally from a screen of homozygous viable single P-element insertion lines that show recessive defects in chemosensory behavior (B. Murugasu-Oei, R. Balakrishnan, W. Chia, and V. Rodrigues, in prep.). Results from reversion experiments have shown that this P-element insertion is responsible for defective chemosensory perception in the third-instar larvae and in adults (data not shown). Using standard methods (see Materials and methods), $\sim 20 \mathrm{~kb}$ of genomic DNA flanking the mas P-element insertion was isolated. Within the cloned region, a single $4-\mathrm{kb}$ transcript was detected that was located $\sim 500$ bp upstream of the P-element insertion. Using the genomic DNAs as probes, cDNA clones were obtained that encompassed the entire coding region of this transcript. The organization of the transcription unit was determined by comparing the cDNA sequence with the genomic sequence. A schematic summary of the organization of the mas transcription unit relative to the genomic DNA is shown (Fig. la,c).

The expression of the mas transcription unit was assessed by Northern hybridization using poly(A) ${ }^{+}$RNA prepared from various developmental stages. The results

Figure 1. Schematic representation of the mas gene, its transcript, deduced protein, and the lesions associated with three P-elementmediated deletion mutations. $(a)$ A restriction map of the genomic region encompassing the mas transcription unit. $(b)$ The structure, deduced from Southern mapping experiments, of three P-element-induced deletion mutants affecting the mas-coding region are schematically represented (see text). (c) The intron/exon organization of mas derived from a comparison of cDNA and genomic sequences. The sizes of the introns are indicated; the $1.6-\mathrm{kb}$ intron in the $5^{\prime}$-transcribed nontranslated region has not been sequenced in its entirety. Horizontal arrow and solid square indicate the putative positions of transcriptional start and stop sites based on a full-length cDNA clone; transcribed but nontranslated regions are indicated by open boxes; protein-coding regions are indicated by solid boxes. The deduced mas protein and structures of deletion mutants are also represented. Absent sequences are shown as a solid bar, with the broken bar indicating the unknown endpoint of the deletion. The restriction sites shown are Bam HI (B), EcoRI (R), HindIII $(\mathrm{H})$, SacI $(\mathrm{Sc}), X m n \mathrm{I}(\mathrm{X}), \operatorname{Pst} \mathrm{I}(\mathrm{P})$, and SalI $(\mathrm{S})$. 
a) Restriction map of mas genomic DNA

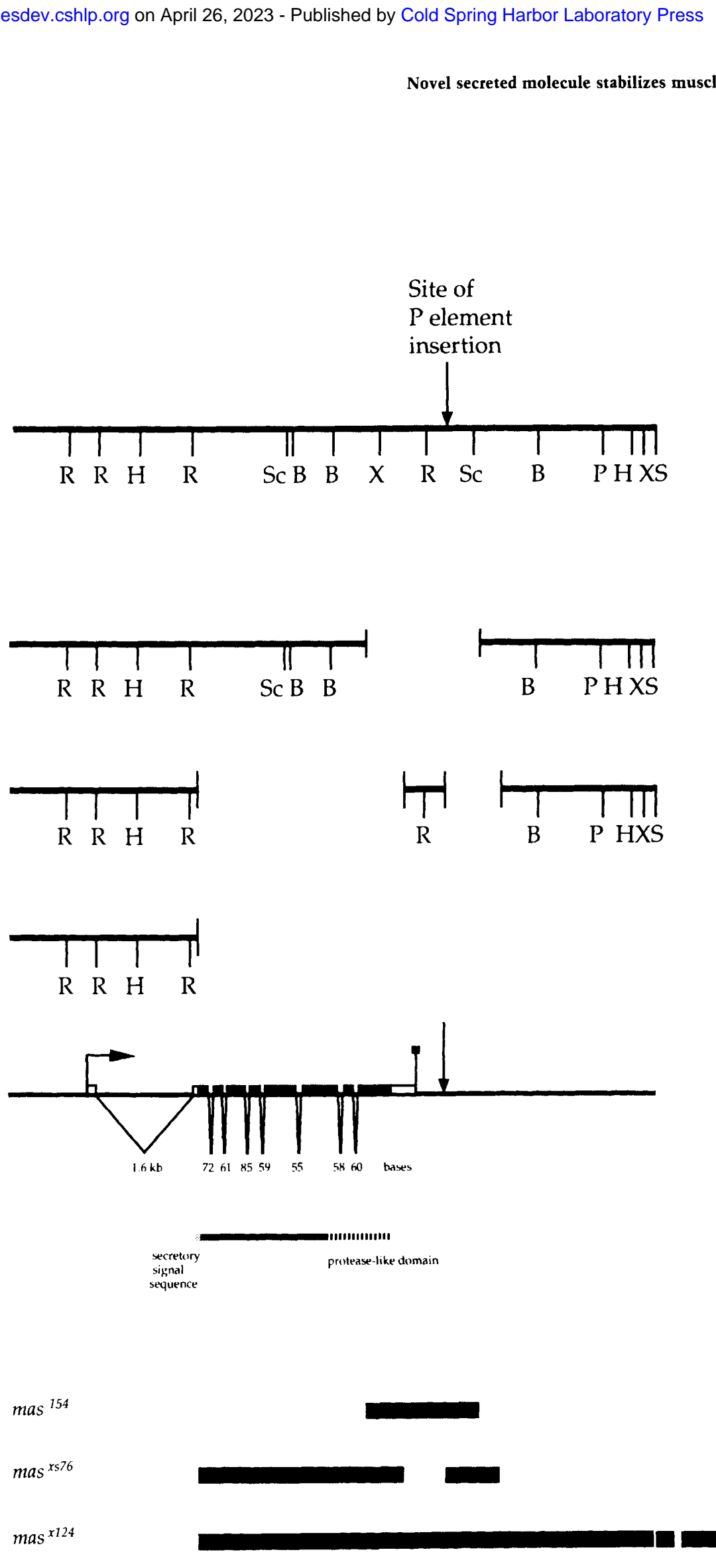

b) mutant alleles

$$
\text { mas } 154
$$
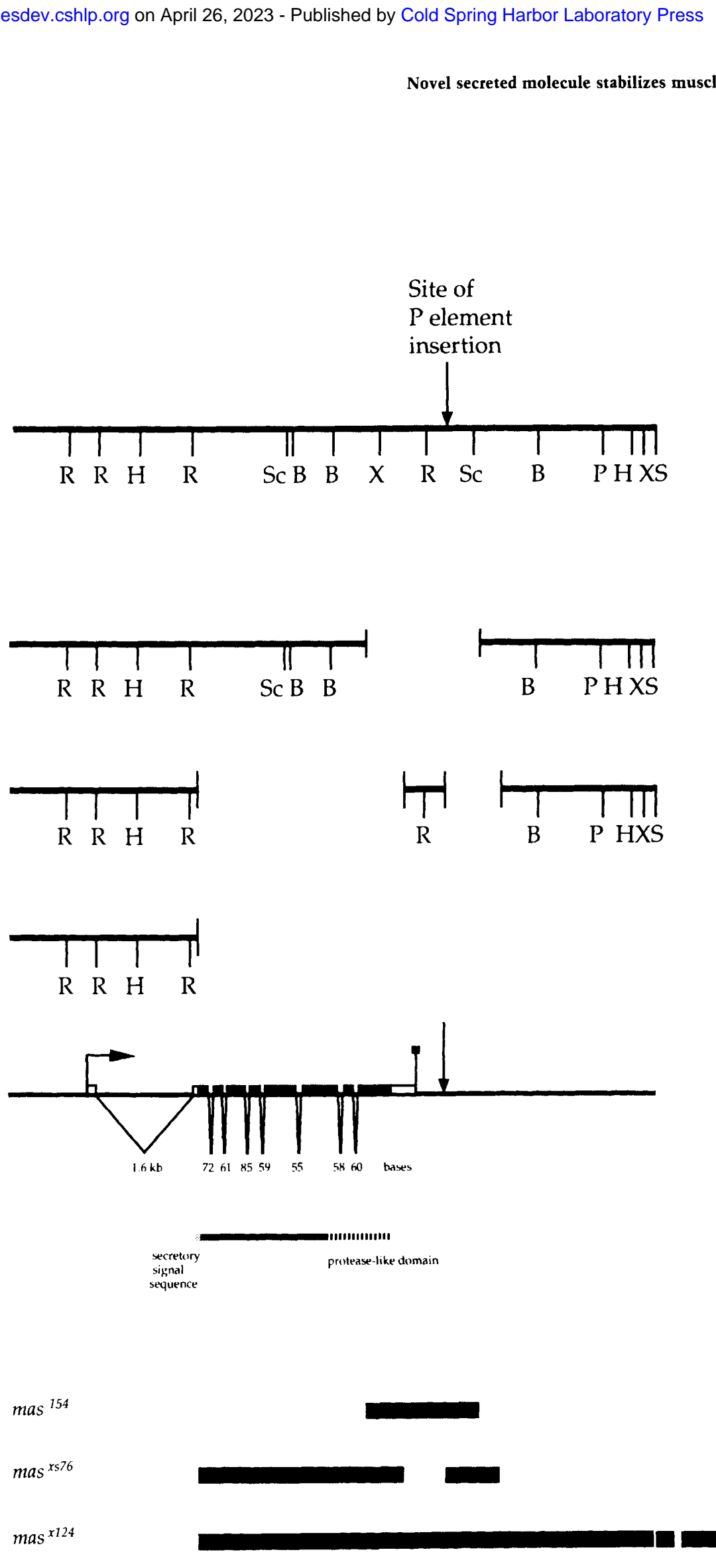

$$
\operatorname{mas} x s 76
$$
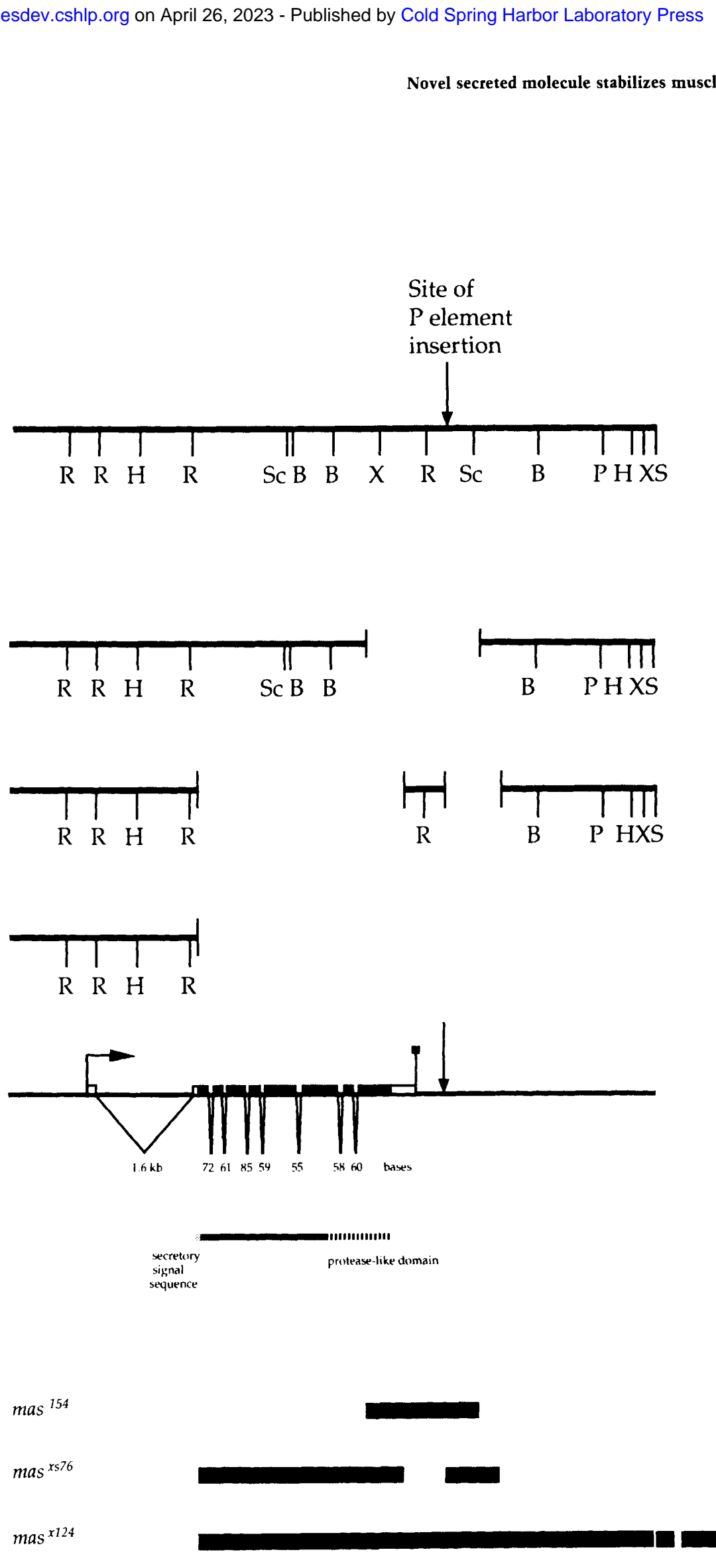

$$
\operatorname{mas} x 124
$$

c) Intron-exon structure

mas protein
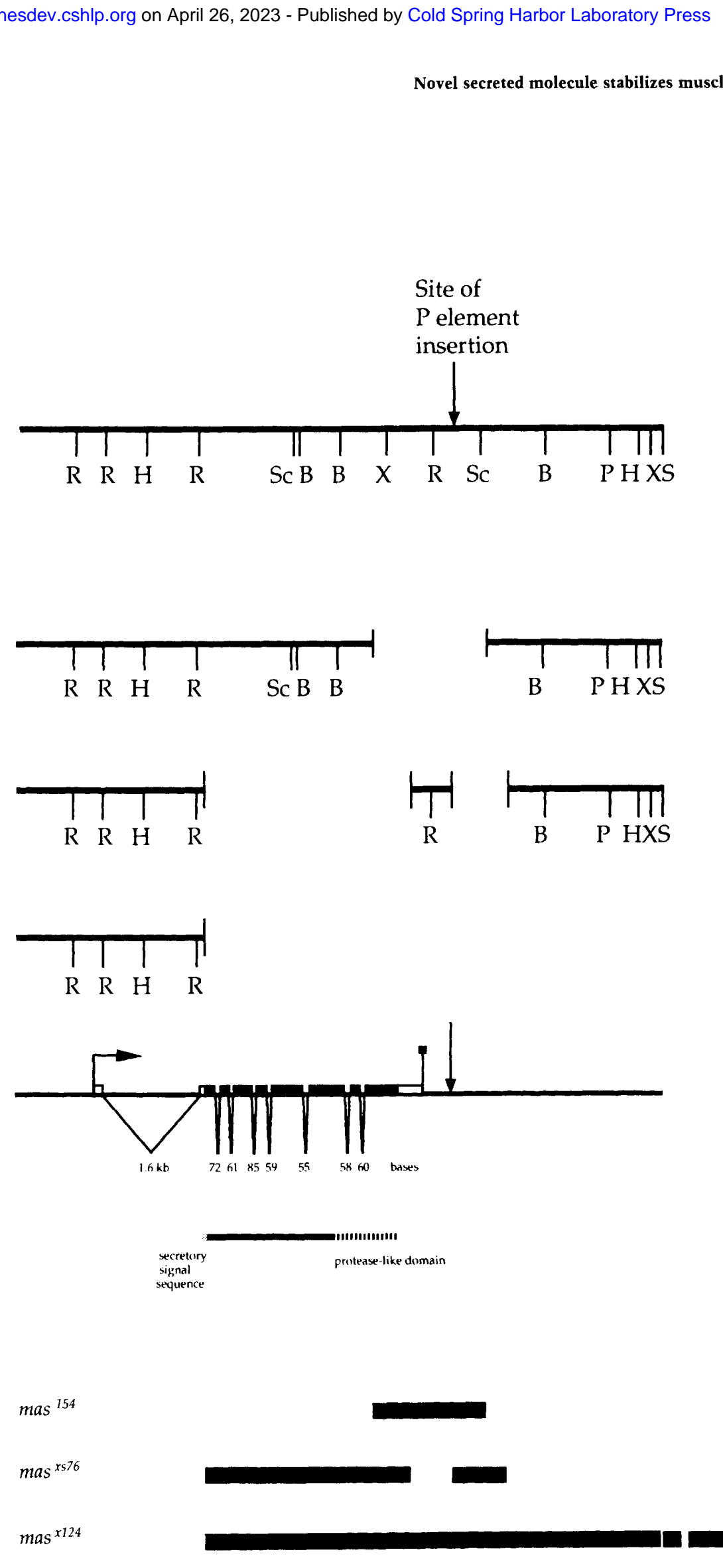

mas
deletions
mas $^{154}$
$\operatorname{mas}^{x 576}$
$\operatorname{mas}^{x 124}$

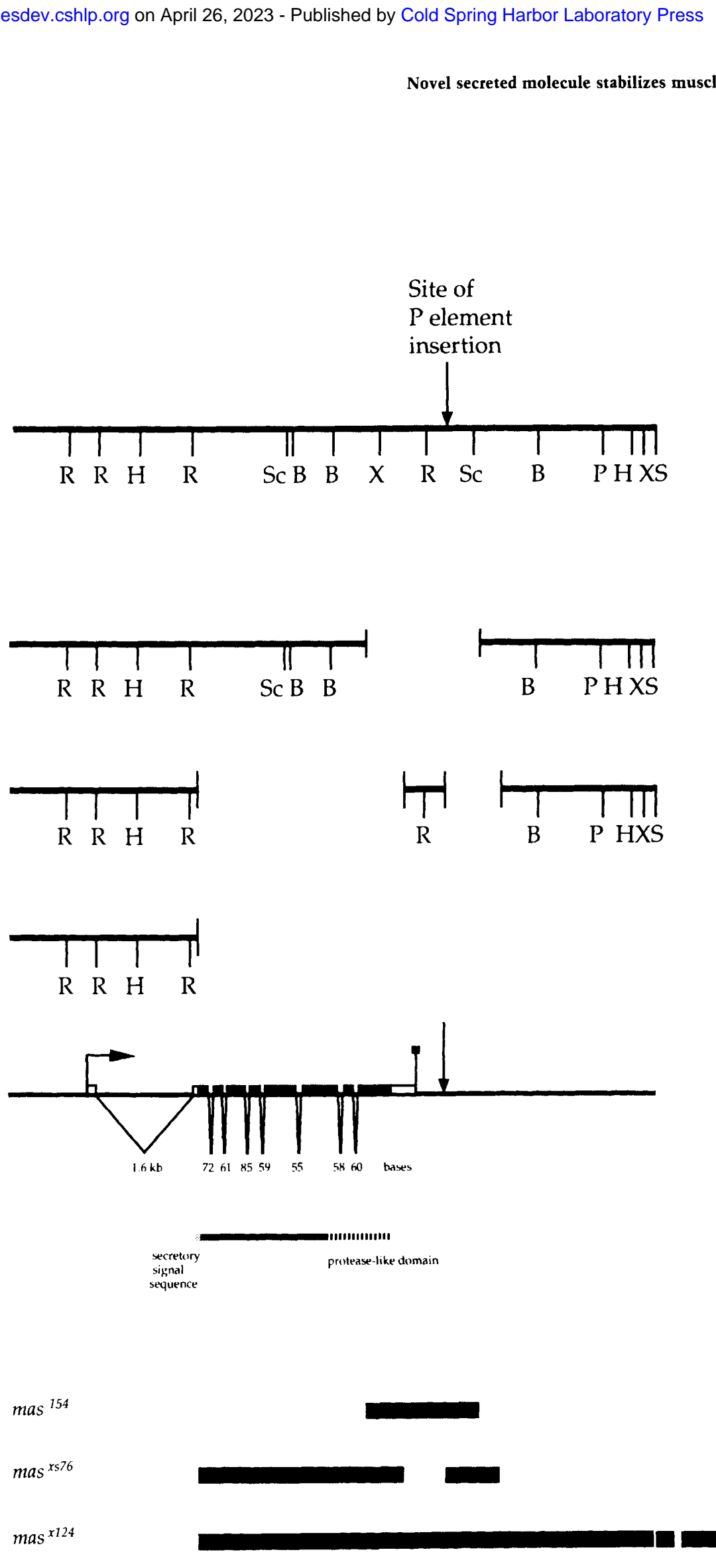

$$
\begin{aligned}
& \text { signal } \\
& \text { sequence }
\end{aligned}
$$

$1 \mathbf{k b}$

Figure 1. (See facing page for legend.) 
(see Fig. 2) indicate that the 4-kb mas mRNA is detected primarily during embryonic, first-instar larval and pupal development.

The original P-element insertion, located at cytological position 64B, clearly did not abolish mas function, because it lies just $3^{\prime}$ to the mas transcription unit and did not cause gross alterations in the mas transcript distribution (not shown). To generate total loss-of-function alleles of mas, we mobilized the original P element and attempted to isolate new insertions into the mas-coding region as well as imprecise excisions that removed the mas-coding region (see Materials and methods). The mutations obtained were analyzed (see Materials and methods), and the structural defects associated with three of the alleles are schematically summarized in Figure 1, b and c. We have analyzed in detail the embryonic phenotype associated with these three alleles that remove either all or part of the mas-coding region. $\operatorname{mas}^{x s 76}$ and mas $^{\times 124}$ are protein minus null alleles (see below) in which the whole of the mas protein-coding region has been removed; in mas ${ }^{154}$, only part of the protease-like portion of the carboxy-terminal region of mas is deleted (Fig. 1c). These mutants are recessive embryonic lethal mutations that exhibit indistinguishable phenotypes either as homozygotes or as transheterozygotes. In addition, we have observed that animals homozygous for mutational lesions farther $3^{\prime}$ to mas, which do not affect the mas transcribed region, are phenotypically normal (not shown).
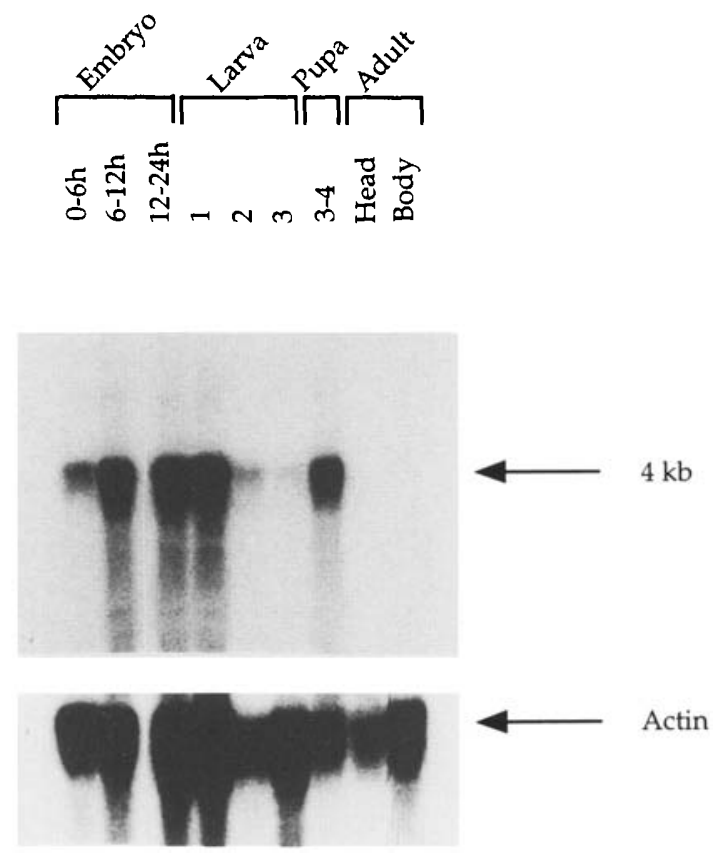

Figure 2. Developmental Northern blot of mas. A Northern filter containing $2 \mu \mathrm{g}$ of polyadenylated RNA from each of the stages indicated was hybridized to a mas cDNA probe (top). The ages of the embryonic samples are given in hours; the ages of the larval and pupal RNA preparations are given in days. The filter was rehybridized to an actin probe as a control for loading (bottom).
Loss of mas function results in defective somatic muscle attachment

To examine the musculature in mutant embryos, we constructed strains bearing the $M h c-l a c Z$ transgene in the mutant background. The $M h c$ promoter directs expression of Escherichia coli $\beta$-galactosidase in all somatic muscles, thus serving as a convenient marker (Hess et al. 1989; Broadie and Bate 1993). Muscle development and patterning are normal in mutants up to stage 15. The defects only become apparent during stage 16 . We often observed muscles that appear collapsed [e.g., in Fig. 3b', lateral transverse muscles 1-3 (LT1-LT3); in Fig. 3b, solid arrowheads] in comparison to their counterparts in normal animals (Fig. 3a, solid arrowheads). The most frequent defects are ones in which the muscles appear rounded up in myospheroid-like bodies [e.g., in Fig. 3c', ventral acute 2 (VA2); in Fig. 3c, solid arrow] or have detached from one side [e.g., in Fig. 3d', ventral lateral 1 (VL1); in Fig. 3d, open arrows]. In some instances, muscles [e.g., in Fig. 3a', lateral oblique 1 (LO1); in Fig. 3a, open arrowhead] appear absent, presumably because they had detached from both ends /absence of LOl in Fig. 3b, $\left.\mathrm{b}^{\prime}\right)$. The overall muscle pattern was, however, not altered significantly, and the structure of muscle fibers appeared intact when examined by polarized light or by activity staining of the $M h c-l a c Z ;$ mas $^{x>76}$ animals. The phenotype of all three alleles is reminiscent of 111 ) mys although not as severe.

To determine whether mas loss of function has an effect on somatic muscles in general or whether the effect is specific to subsets of muscles, a quantitative analysis of the phenotype was performed for two of the mas mutant alleles $\left(\right.$ mas $^{154}$ and $\left.\operatorname{mas}^{x s 76}\right)$. In these experiments, we scored individual muscles in whole mounts of homozygous mutant animals and control embryos stained with anti-MHC (Kiehart and Feghali 1986); for ease of scoring, we examined primarily the ventral and lateral somatic muscles (although similar results are seen with the dorsal muscles from a smaller data set). Our results (Table 1) indicate that animals homozygous for the mas loss-of-function alleles $\left(\right.$ mas $^{154}$ and mas $\left.^{x{ }^{x 6}}\right)$ show a frequency of muscle attachment defects one and one-half orders of magnitude higher than those seen in wild-type animals and in animals homozygous for a precise excision of the original mas insertion line. Moreover, the defects seen in the mutants appear to affect all the somatic muscles at similar frequencies. These observations clearly indicate a general role for mas in somatic muscle attachment and are consistent with the view that mas acts to promote and/or stabilize cell-matrix interactions.

mas encodes a putative secreted molecule sharing many of the structural features of serine protease zymogens but is unlikely to possess protease activity

DNAs covering the whole of the mas protein-coding region were isolated and sequenced. The largest open reading frame starting with a methionine is 1047 amino ac- 
Novel secreted molecule stabilizes muscle attachment

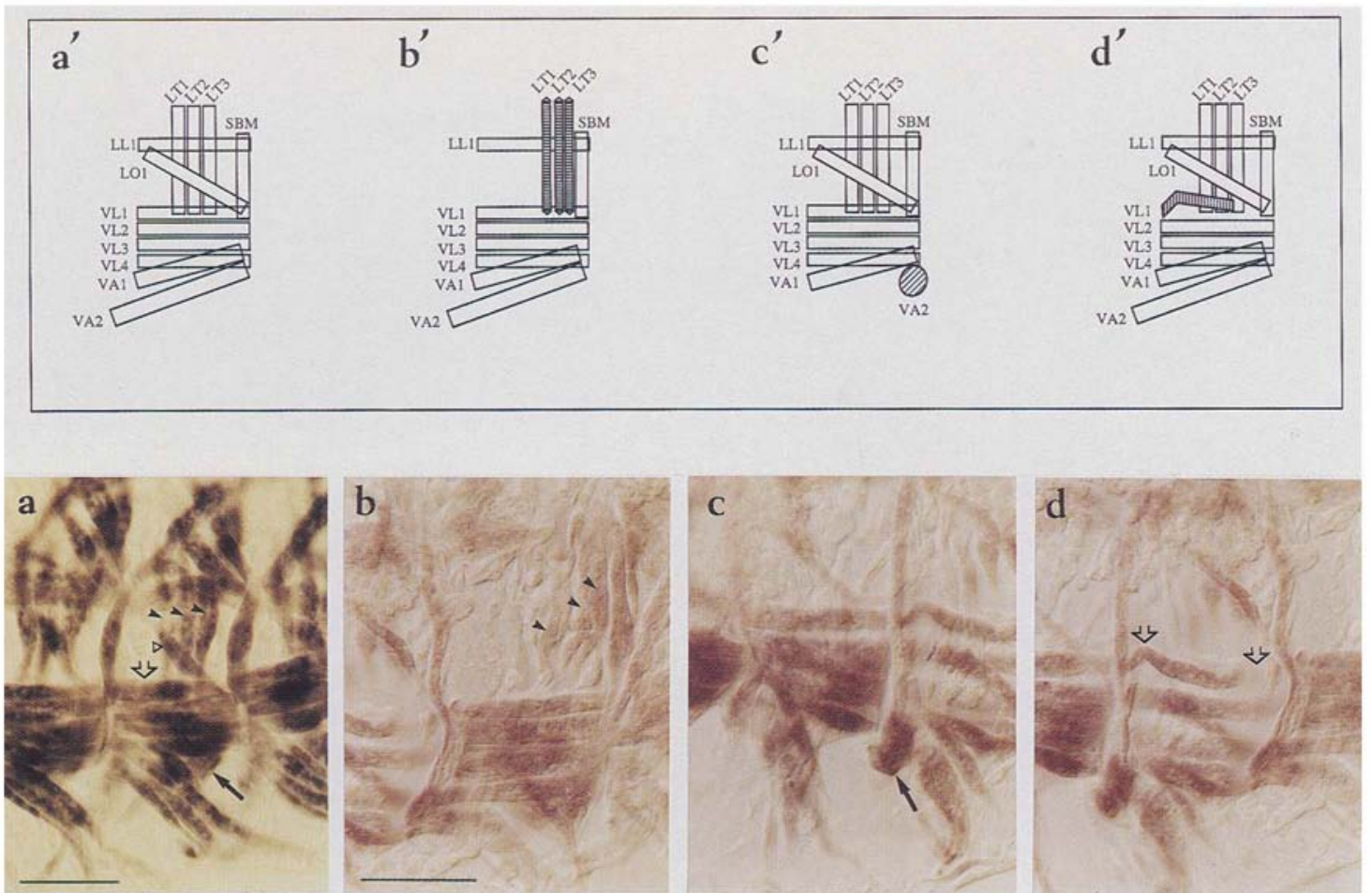

Figure 3. Null mutations of mas cause defective muscle attachment. Muscle nomenclature is according to Bate (1993). The somatic musculatures of the abdominal segments of dissected embryonic preparations of wild-type $(a)$ and mutant $(b-d)$ animals were examined. Both the wild-type and mutant animals carry an insertion ( $M h c-l a c Z$ ), in which the E. coli lacZ expression is driven by a myosin heavy-chain promoter, which allows the somatic muscles to be visualized by staining with anti- $\beta$-galactosidase. Schematic drawings showing the relevant muscles are given immediately above each panel $\left(a^{\prime}-d^{\prime}\right)$. Anterior is to the left and dorsal is toward the top. (a) A wild-type hemisegment from an Mhc-lacZ embryo; muscles LT1-LT3 (solid arrowheads), muscle LO1 (open arrowhead), muscle VL1 (open arrow), and muscle VA2 (solid arrow), which lies just below the plane of focus, are indicated. (b) A mutant hemisegment (from an $M h c-l a c Z ;$ mas $^{x s 76}$ embryo) in which muscles LT1-LT3 have detached and collapsed (solid arrowheads; horizontal stripes in $b^{\prime}$ ) and muscle $\mathrm{LOl}$ is absent. (c) A mutant hemisegment in which muscle VA2 has rounded up into a ball-like structure (solid arrow; hatched circle in $\left.c^{\prime}\right) .(d)$ A mutant segment in which muscle VLl appears to have detached from one of its attachment sites (open arrows; vertical stripes in $\left.d^{\prime}\right)$. Similar results are seen with the other mas alleles described in Fig. 1d (also see Table 1$)$. Bars $(a, b), 25$ $\mu \mathrm{m}$.

ids, although the sequence context of the second methionine (at codon 8) has a better agreement with the consensus sequence for translational initiation (Cavener 1987). Translational termination codons are found in all three reading frames upstream of the putative initiation codon. The mas nucleotide and amino acid sequences (Fig. 4), as well as a schematic representation (Fig. 5a) showing the major structural features of the deduced protein, are shown. A hydrophobic sequence that immediately follows the initiation methionine is probably a signal peptide (von Heijne 1985); inspection of the amino-terminal residues suggests that the first 30 amino acids comprise a presequence and that signal sequence cleavage occurs between residues 30 and 31 (von Heijne 1986).

The protein contains five repeats of a disulfide knotted motif that has been found in other arthropod serine proteases (Gay and Keith 1992), including the Drosophila $S b$-sbd (Appel et al. 1993), snake (DeLotto and Spierer 1986), and easter (Chasan and Anderson 1989) gene products and the Limulus proclotting protein (Muta et al.
1990|. For the Limulus proclotting protein, it has been demonstrated that intramolecular disulfide bridges formed between the 6 cysteine residues (found in each of these motifs) result in the formation of a knot-like structure that is thought to act as a receptor for the protein that cleaves at the zymogen activation site. Like other protease zymogens, there are stretches where single amino acids of $G, E, P$, and $T$ are repeated. Interspersed among the disulfide knots and the amino acid repeats are six putative $\mathrm{N}$-glycosylation sites.

The carboxy-terminal domain possesses many of the features associated with serine proteases (see Fig. 5b); however, the position normally occupied by the serine residue within the invariant catalytic triad essential for catalysis has been replaced by a glycine. The authenticity of this glycine has been confirmed by sequencing of both the genomic and two independent cDNA clones. Hence, mas is unlikely to possess protease activity. The residues lining the substrate binding pocket have also been conserved (see Fig. 5b), and the substrate binding pocket most resembles those of the trypsin-like serine 
Table 1. Quantitative analysis of the muscle detachment phenotype in mas mutants

\begin{tabular}{|c|c|c|c|c|c|c|c|c|c|c|c|c|c|c|}
\hline \multirow[b]{2}{*}{ Muscle } & \multicolumn{14}{|c|}{$\begin{array}{c}\text { Ventral muscles } \\
\text { (number of defective muscles/total number of muscles) }\end{array}$} \\
\hline & VAl & VA2 & VA3 & VOl & $\mathrm{VO} 2$ & VO3 & VO4 & VO5 & VO6 & VLl & VL2 & VL3 3 & VL4 & VTl \\
\hline \multicolumn{15}{|c|}{ Genotype } \\
\hline WT & $0 / 137$ & $0 / 137$ & $0 / 137$ & $0 / 137$ & $0 / 137$ & $0 / 137$ & $0 / 137$ & $0 / 137$ & $0 / 117$ & $0 / 137$ & $0 / 137$ & $0 / 137$ & $0 / 137$ & $1 / 117$ \\
\hline Rev & $0 / 136$ & $0 / 136$ & $0 / 136$ & $1 / 136$ & $1 / 136$ & $0 / 136$ & $0 / 136$ & $0 / 136$ & $0 / 122$ & $0 / 136$ & $0 / 136$ & $0 / 136$ & $1 / 136$ & $0 / 122$ \\
\hline $\operatorname{mas}^{154}$ & $30 / 138$ & $33 / 138$ & $39 / 138$ & $31 / 138$ & $31 / 138$ & $29 / 138$ & $29 / 138$ & $31 / 138$ & $28 / 118$ & $19 / 138$ & $21 / 138$ & $18 / 138$ & $18 / 138$ & $29 / 118$ \\
\hline \multirow[t]{2}{*}{$\operatorname{mas}^{x s 76}$} & $37 / 140$ & $35 / 140$ & $40 / 140$ & $32 / 140$ & $32 / 140$ & $33 / 140$ & $31 / 140$ & $36 / 140$ & $32 / 120$ & $24 / 140$ & $29 / 140$ & $30 / 140$ & $31 / 140$ & $27 / 120$ \\
\hline & & \multicolumn{13}{|c|}{$\begin{array}{l}\text { Lateral muscles } \\
\text { (number of defective muscles/total number of muscles) }\end{array}$} \\
\hline \multicolumn{2}{|l|}{ Muscle } & SBM & & LOl & & LLl & & LTI & & LT2 & & LT3 & & LT4 \\
\hline \multicolumn{15}{|c|}{ Genotype } \\
\hline \multirow{5}{*}{$\begin{array}{l}\text { WT } \\
\text { Rev } \\
\operatorname{mas}^{154} \\
\operatorname{mas}^{5 \times 76}\end{array}$} & & $1 / 137$ & & $0 / 137$ & & $0 / 137$ & & $1 / 137$ & & $0 / 137$ & & $3 / 137$ & & $5 / 137$ \\
\hline & & $0 / 136$ & & $2 / 136$ & & $2 / 136$ & & $1 / 136$ & & $1 / 136$ & & $3 / 136$ & & $3 / 136$ \\
\hline & & $19 / 138$ & & $35 / 138$ & & $22 / 138$ & & $21 / 138$ & & $22 / 138$ & & $28 / 138$ & & $33 / 138$ \\
\hline & & $28 / 140$ & & $37 / 140$ & & $41 / 140$ & & $28 / 140$ & & $28 / 140$ & & $32 / 140$ & & $38 / 140$ \\
\hline & & & & & & & & VT & & vertant & & $\operatorname{mas}^{154}$ & & $\operatorname{mas}^{x s^{76}}$ \\
\hline \multirow{2}{*}{\multicolumn{7}{|c|}{ Number of defective hemisegments/total number of hemisegments }} & \multirow{2}{*}{\multicolumn{2}{|c|}{$\frac{6}{137}$}} & \multicolumn{2}{|r|}{9} & \multicolumn{2}{|r|}{127} & \multirow{2}{*}{\multicolumn{2}{|c|}{$\frac{130}{140}$}} \\
\hline & & & & & & & & & & $\overline{136}$ & & $\overline{138}$ & & \\
\hline \multicolumn{7}{|c|}{ Defective hemisegments $(\%)$} & \multicolumn{2}{|c|}{4.4} & \multicolumn{2}{|r|}{6.6} & \multicolumn{2}{|r|}{92.0} & & 92.9 \\
\hline
\end{tabular}

Nomenclature of the muscles is according to Bate (1993). Defective muscles are defined by the phenotypes described in Fig. 3, b-d. Muscles phenotypes of abdominal segments 1-7 were assessed at embryonic stage 16 using anti-MHC antibodies (Keihart and Feghali 1986). (WT) Wild type; (Rev and Revertant) precise excision of the original mas P-element insertion, as determined by Southern blot analysis; $\left\{\right.$ mas ${ }^{154}$ and mas ${ }^{x 7} \sigma^{\prime}$ mas mutant alleles (see Fig. 1d!.

proteases that cleave after basic amino acid residues. The 6 cysteines that form disulfide bonds within the protease domain of other serine proteases are also found at conserved positions in the carboxy-terminal domain of mas.

\section{mas is specifically processed to generate two polypeptides}

The structural features of the predicted mas protein show striking similarities to serine proteases, many of which are activated by processing (zymogen activation). To examine the possibility that mas is also processed, we produced affinity-purified antibodies against two antigens; a synthetic peptide (residues 164-188) corresponding to a region of mas lying near the amino terminus and a fusion protein that includes the mas carboxy-terminal modified serine protease domain (see Fig. 5a; Materials and methods). That these antibodies specifically recognize mas is supported by the observation that they fail to stain animals homozygous for a mutation that deletes the mas coding region (see Fig. $8 \mathrm{e}, \mathrm{f}, \mathrm{m}-\mathrm{o}$, below). With wild-type embryos, the in situ patterns of staining seen with the two antibodies differ (see Fig. 8a-d,g-l); these observations are consistent with the notion that mas is processed to generate distinct polypeptides that are differentially recognized by the two purified sera.

In Western experiments using 0 - to 22 -hr embryonic lysates, the purified serum raised against the amino-terminal synthetic peptide specifically recognizes a $35-\mathrm{kD}$ band (Fig. 6a, lane 3), whereas the purified serum raised against the carboxy-terminal fusion protein specifically recognizes a $77-\mathrm{kD}$ band (Fig. $6 \mathrm{a}$, lane 1). A $112-\mathrm{kD}$ band seen in some but not all preparations is consistent with the existence of a transient proprotein that is processed into an amino-terminal and a larger carboxy-terminal polypeptide. The $35-$ and $77-\mathrm{kD}$ bands were not seen when the experiments were done with the preimmune sera (Fig. 6a, lanes 2,4 ). To further ascertain the authenticity of these bands, an additional control was done, using a strain (hs-mas) homozygous for a transposon insertion carrying a transgene in which the full-length mas cDNA is placed under the control of the $h s p 70$ promoter. hs-mas embryos were collected during a developmental interval when there is normally no detectable mas protein expression (2-5 hr) and subjected to a 1-hr heat shock at $37^{\circ} \mathrm{C}$ (see Materials and methods). Two hours following heat shock, accumulation of both the $77-\mathrm{kD}$ (Fig. 6b, lane HS) and the $35-\mathrm{kD}$ (Fig. 6c, lane HS) polypeptides is readily detected in Western blots using the appropriate purified serum. In the corresponding control embryos that were not subjected to heat shock, little if any of the $77-\mathrm{kD}$ (Fig. 6b, lane C) and 35-kD (Fig. 6c, lane C) polypeptides can be detected, because mas protein expression does not normally occur until late in embryogenesis (see below). These data indicate clearly that the mas protein is processed into two polypeptides of $35 \mathrm{kD}$ (amino-terminal) and $77 \mathrm{kD}$ (carboxy-terminal). The processing mechanism therefore appears to be ubiquitous and is present during stages preceding the normal appearance of the mas protein. 


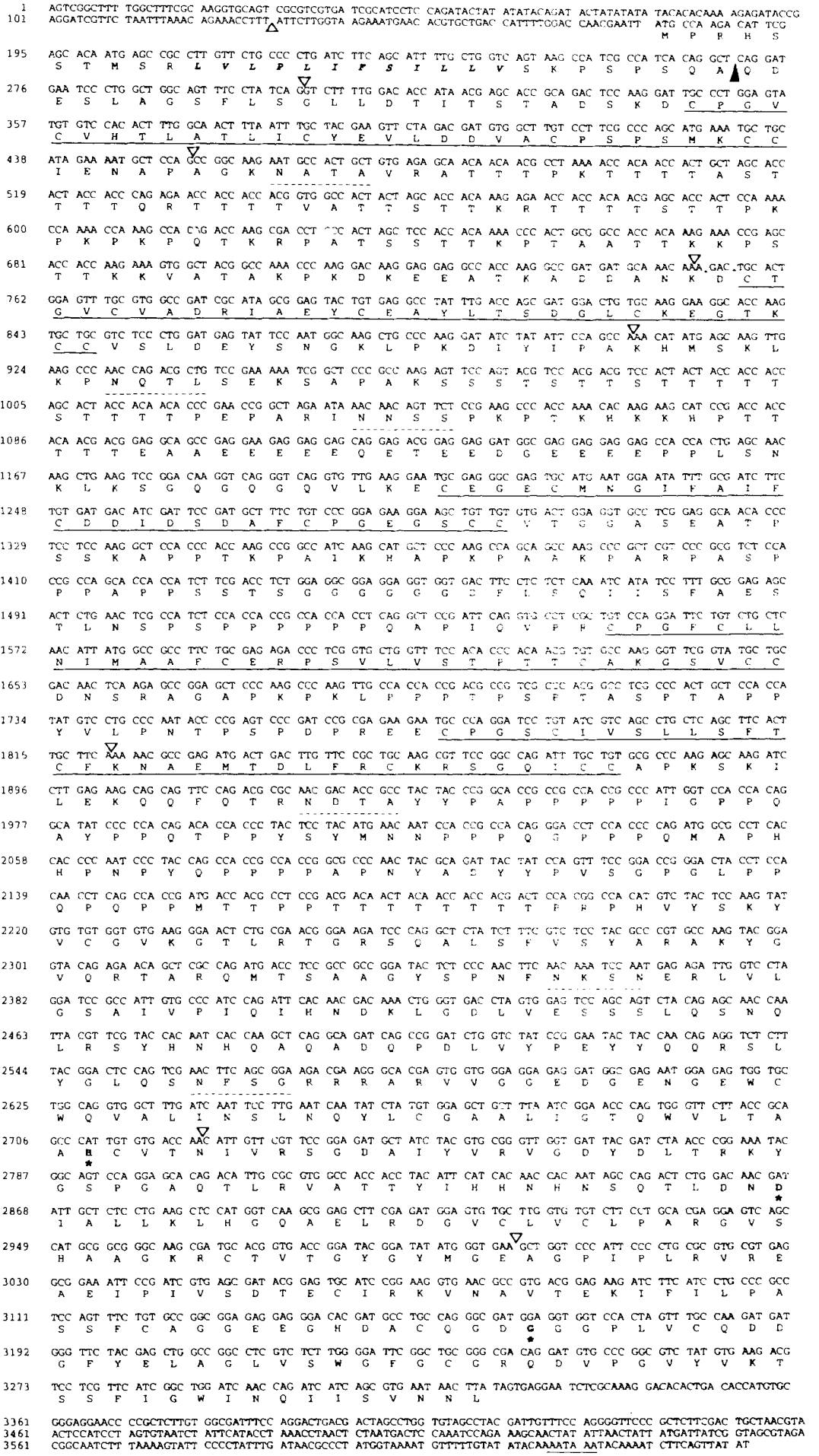

Figure 4. The nucleotide and deduced amino acid sequence of mas. The nucleotide sequence of the full-length mas cDNA, excluding the run of $A^{\prime} s$ at the $3^{\prime}$ end, is shown along with the amino acid sequence of the longest deduced open reading frame starting with a methionine. The locations of the putative signal peptide (bold italics), signal peptidase cleavage site (arrowhead), N-glycosylation sites (broken lines), disulfide knotted domains (underline), introns (open arrowheads), and polyadenylation site (double underline) are shown. The amino acids occupying positions that in serine proteases correspond to the triad of residues responsible for catalysis (see text) are in bold and indicated with asterisks (*). There are several potential protein cleavage sites between residues 330 and 357 .

\section{The mas RNA expression pattern}

The mas RNA expression pattern was assessed using the whole-mount in situ method (Tautz and Pfeifle 1989). The earliest expression of mas RNA is seen at stage 11 in small cells along the midline of the central nervous system (CNS) that persists until the end of stage 13 (Fig. $7 \mathrm{~b}, \mathrm{c}, \mathrm{e}, \mathrm{f}$, fine arrow); we have not been able to identify these cells. mas RNA expression is seen in the epidermis starting at stage 12 as lateral patches of cells (Fig. 7a-c, solid arrowhead); during stage 13 , the number of expressing cells increases (Fig. $7 \mathrm{~d}, \mathrm{f}$, solid arrowhead); from stage 14 onwards (Fig. $7 \mathrm{~g}, \mathrm{i}$ ), the great majority of epidermal cells express mas RNA, although a few nonexpressing cells can be seen; the level of staining is highest at the anterior border of each segment (Fig. 7g,i, open arrow- 


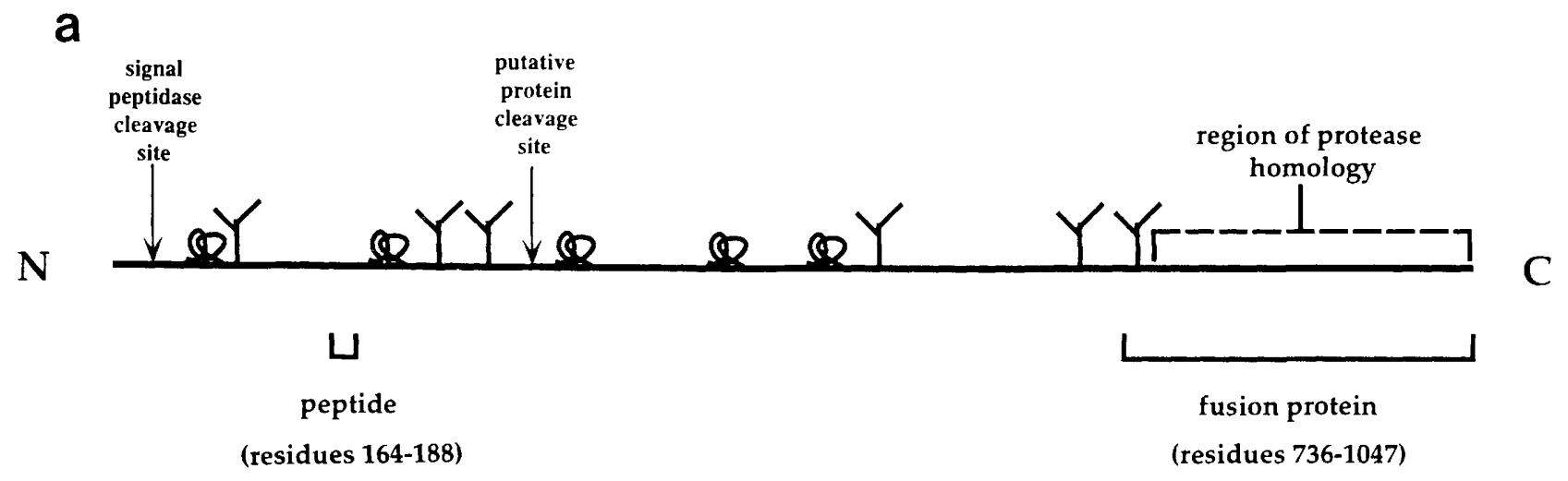

Figure 5. The main structural features of the mas protein. $(a)$ The deduced mas protein is schematically represented; the approximate locations of the consensus signal peptidase cleavage site and the putative protein cleavage site (arrows), the five disulfide knotted domains (knotted symbol), and six putative $\mathrm{N}$-glycosylation sites (Y symbol) are indicated. The region bearing homology to serine proteases is shown. The locations of the peptide sequence (amino acids 164-188) and the fusion protein (which includes amino acids 7361047) used to generate antibodies against the mas protein are indicated. (b) The carboxy-terminal region of the predicted mas protein (amino acids 801-1047) aligned against four members of the trypsin serine protease superfamily. (CHY) Chymotrypsinogen (Smillie and Hartley 1966); (TRY) trypsin (Hermodson et al. 1973); (PLA) macaque plasminogen precursor (Tomlinson et al. 1989); (SNK) snake, a putative Drosophila serine protease (DeLotto and Spierer 1986). Generally conserved residues within the serine protease catalytic region are in boldface type. (") Positions corresponding to the residues of the catalytic triad (note the substitution of glycine for the conserved serine in mas). ( $\nabla)$ Residues in the substrate binding pocket important in determining substrate specificity. The three pairs of cysteines forming disulfide bonds within the serine protease domain are joined.

\begin{tabular}{|c|c|}
\hline MAS & ARVVGGEDGENGEWCWQVAL INSLNQYL . . . . . CGAALIGTQWVLTAABCVTNIVRSGD \\
\hline $\mathrm{CHY}$ & AR I VNGEDAVPGSWPWQVSLQDSTGFHF . . . . . CGGSLISEDWVVTAAHCGVTTSDVVV \\
\hline TRY & DKIVGGYTCAANSI PYQVSL . NSGSHF . . . . . . CGGSLINSQWVVSAAHC . . . . YKS \\
\hline PLA & GRVVGGCVAYPHSWPWQISLRTRLGMHF . . . . . CGGTLISPEWVLTAAHCLEKSSRPS. \\
\hline \multirow[t]{2}{*}{ SNK } & PLIVGGTPTRHGLF PHMAALGWTQGSGSKDQDI KWGCGGALVSELYVLTAAHCATSGANHRT \\
\hline & $\star$ \\
\hline MAS & AIYVRVGDYDL . . TR . . KYGS . . . PGAQTLRVATTYIHHNHNSQTLDNDIALLKLHGQAE \\
\hline $\mathrm{CHY}$ & AGEFDQGLETE . DTQVLKIGKVFKNPKFSIL . . . . . . . . . TVRNDI TLLKLATPAQ \\
\hline TRY & RIQVRLGEHNI . D . VLEGNE . . . . . . QF INAAKI ITHPNFNGNTLDNDIMLIKLSSPAT \\
\hline PLA & .FYKVILGAHR . EVHLE . . . . . . . PHVQEIEVSKMF . . . . . SEPARADIALLKLSSPAI \\
\hline SNK & WFAWR PQLNETSATQQDIKILIIVLHPKYR . . . . . . . . SSAYYHDIALLKLTRRVK \\
\hline MAS & LRDGVCLVCLPARGVSHAAGKRCTVT . . GYGYMGE. AGP I PLRVREAEI PIVSDTEC . . IR \\
\hline CHY & FSETVSAVCLPSADEDF PAGMLCATT . . GWGKTKYNALKTPDKLQQATLPIVSNTDC . RK \\
\hline TRY & LNSRVATVSLP . RSCA . AAGTECLIS . . GWGNTKSSGSSYPSLLQCLKAPVLSDSSC . . . \\
\hline PLA & ITDKVI PACLPSPNYVVADRTECF IT . . . GWGETQ . GTYGAGLLKEARLPVIENKVC . . NR \\
\hline \multirow[t]{2}{*}{ SNK } & FSEQVRPACLWQCG . APHT . . . . TVVAAGWGRTEFL . GAKSNALRQVDLDVSPQMTCKQI . \\
\hline & $\mid \nabla \quad * \quad \nabla \quad \nabla$ \\
\hline MAS & KVNAVTEKIFIL . . PASSFCAGGEEGH . DACQGDGGGP . . LVCQDDGFYELAGLVSWGFG. \\
\hline CHY & YWGSRVTDVMI . . . . . . CAGAS.GV.SSCMGDSGGP . . LVCQKNGAWTLAGIVSWGSST \\
\hline TRY & KSSY . PGQI . . . . TGNM I CVGF LEGGKDSCQGDSGGP . . VVCNGQ . . . LQGIVSWGYG . \\
\hline PLA & . YEFLNGT . V. . KTTELCAGHLAGGTDSCQGDSGGP . . LVCFEKDKY ILQGVT SWGLG. \\
\hline \multirow[t]{2}{*}{ SNK } & YRKERRLPRGI IE . GQ . FCAGYLQAQ . GHCQGDSGGPIHALL PEYNCVAFVVGITSFGKF. \\
\hline & 1 $\nabla$ \\
\hline MAS & CGRQDVPGVYVKTSSF I GWINQI ISVNNL \\
\hline $\mathrm{CHY}$ & c. STST PAVYARVTALMPWVQETLAAN \\
\hline TRY & CAQKNKPGVYTKVCNYVNWIQQTIAAN \\
\hline PLA & CARPNKPGVYVRVSRFVTWIEGVMRNN \\
\hline SNK & CAAPNAPGVYTRLYSYLDWIEKIAFKQH \\
\hline
\end{tabular}

head). mas RNA is also detected in the cells of the tracheal system from stage 14-17 (Fig. 7k,1, thick arrow).

\section{mas protein expression}

We probed embryos with antibodies that recognize the amino-terminal and carboxy-terminal regions of the mas protein (see Fig. 5a; Materials and methods). The expression patterns reveal interesting aspects of the differential localization of the two processed polypeptides. The amino-terminal antibody labels epidermal cells and the membrane of cells of the tracheal system. Staining in the epidermal cell membrane is first detected at stage 14 and increases in intensity until stage 17 /a stage 16 embryo is shown in Fig. 8a); in the older embryos, the strongest staining is associated with the denticles (Fig. 8b, arrowhead). There is an apparent lag between the times at which the mas RNA (stage 12) and protein expression (stage 14) are first detected in the epidermis. Staining in the tracheal system can be seen from stage 14-17 (Fig. $8 \mathrm{c}, \mathrm{d}$ ); the staining appears to be primarily in the cells lining the tracheal lumen (see Fig. 8d, arrow).

The pattern of expression seen with the anti-fusion protein antibody (see Fig. 5a; Materials and methods), which recognizes the carboxy-terminal $77-\mathrm{kD}$ polypeptide on Western blots, is shown in Figure $8, \mathrm{~g}-\mathrm{l}$. The most intense staining is seen in the attachment sites of somatic embryonic muscles late in embryogenesis, starting in early stage 16 (Fig. 8h, fine arrow; Fig. 8l, long arrow) and persisting until the beginning of pupation 


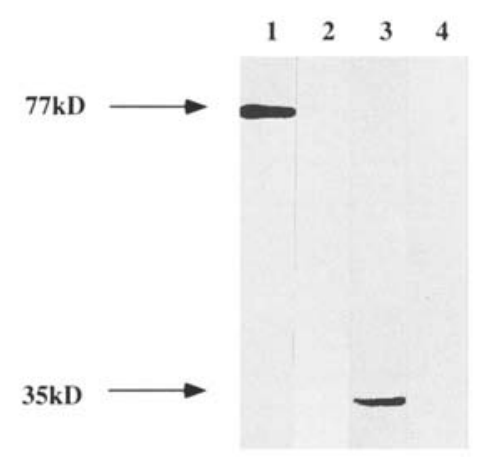

b)

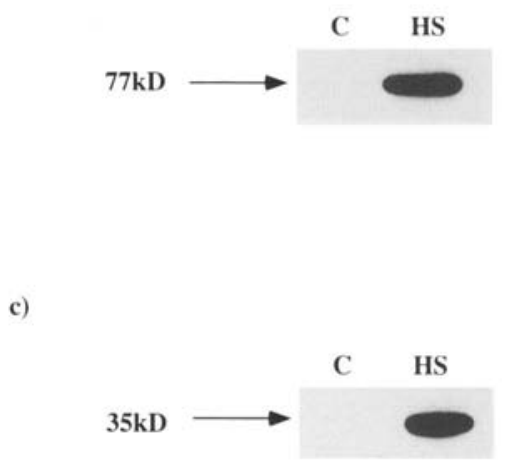

Figure 6. The mas protein is processed to give two cleavage products. Western blot analyses. (a) 12- to 24-hr wild-type embryonic extracts with mas carboxy-terminal fusion antibody (lane 1), preimmune serum prior to the production of carboxy-terminal antibody (lane 2), amino-terminal peptide antibody (lane 3), and preimmune serum prior to the production of the amino-terminal antibody (lane 4). $(b, c)$ A transgenic line was established in which the mas cDNA was placed under the control of the hsp 70 promoter (hs-mas). Embryos (2-5 hr) were given a 1 -hr heat pulse and allowed to recover for 2 hr (lanes $H S$ ); the embryonic extracts were compared with the extracts of 5- to 8-hr uninduced $h s$-mas (lanes $C$ ) by probing with anti-carboxy-terminal antibody $(b)$ and antiamino-terminal antibody $(c)$. (data not shown). Whole-mount in situ hybridization does not detect mas RNA in muscle (see previous section), suggesting that the carboxy-terminal moiety recognized by the fusion antibody is secreted into the intercellular region of the attachment site by the epidermal cells. Further evidence for the secretion of the carboxyterminal polypeptide is provided by its localization in the tracheal lumen (Fig. 8g,j, thick arrow), which is clearly extracellular. In the CNS, mas RNA is found in some unidentified cells in the midline (see previous section), whereas the carboxy-terminal antibody not only stains these cells (Fig. 8i, open arrowhead) but also the axons of the longitudinal connectives (Fig. 8g,h,k, solid arrowhead), again consistent with the carboxy-terminal polypeptide being secreted.

\section{Discussion}

We argue that the muscle phenotype observed in animals null for mas function is attributable to a decrease in cell-matrix adhesion. Sequence analysis and biochemical data suggest that mas is produced as a preproprotein that is processed to release an extracellular carboxy-terminal polypeptide. The correlation of its distribution and the loss-of-function phenotype suggests that the carboxy-terminal polypeptide is the functional portion of mas. The mas protein, as a whole, contains many structural features found in serine proteases; however, the catalytic serine residue is replaced by a glycine, making it unlikely to possess enzymatic activity. We suggest two mutually nonexclusive models for how mas might act to stabilize cell-matrix interactions. In the first model, we propose that mas acts as a novel substrate adhesion molecule and directly promotes cell-substrate adhesion. In this scenario, the conserved serine protease motif, which is normally employed to facilitate protease-substrate interactions, has been adapted in mas for a similar role in mediating protein-protein interactions. An alternative model would be that mas acts to counteract the effects of serine proteases /which can affect cellular morphology either directly, by cleavage of proteins involved with the anchoring of cell surface to the substratum, or indirectly through the activation of cell surface receptors). In this scenario, we propose that mas competes for serine protease substrates and behaves, effectively, as a competitive serine protease antagonist to indirectly stabilize cell-substrate interactions.

Loss-of-function muscle phenotype suggests a role for mas in the maintenance of cell-matrix interactions

The observation that the formation of the somatic muscle attachments occurs prior to the accumulation of the carboxy-terminal polypeptide of mas suggests that this molecule plays a role in the maintenance of muscleepidermal adherence. The phenotype of the null alleles further substantiates this view because the mutant animals show detachment of the somatic muscles (stage 16 and later) around the time of the first muscular contractions. Ultrastructural studies of somatic muscle attachment sites indicate that there are matrix components lying between the adhering epidermal and mesodermal structures. It is thought that the binding of the PS integrins, found on the apposed cells, to sites on the matrix would facilitate the formation of the attachment site. The defects in muscle attachments seen in the mas mutants suggest a role for mas in stabilizing this type of cell-matrix binding. As would be expected for this proposed role, the effect of the absence of mas function is general to all somatic muscles; moreover, the incomplete expressivity of the phenotype can be explained by the presence of other ECM molecules that can partially compensate for the absence of mas.

The defect caused by mas loss of function coincides with the localization of the carboxy-terminal modified protease domain of mas at muscle attachment sites

The carboxy-terminal polypeptide of mas appears to be the functional portion of the mas protein; its localization 

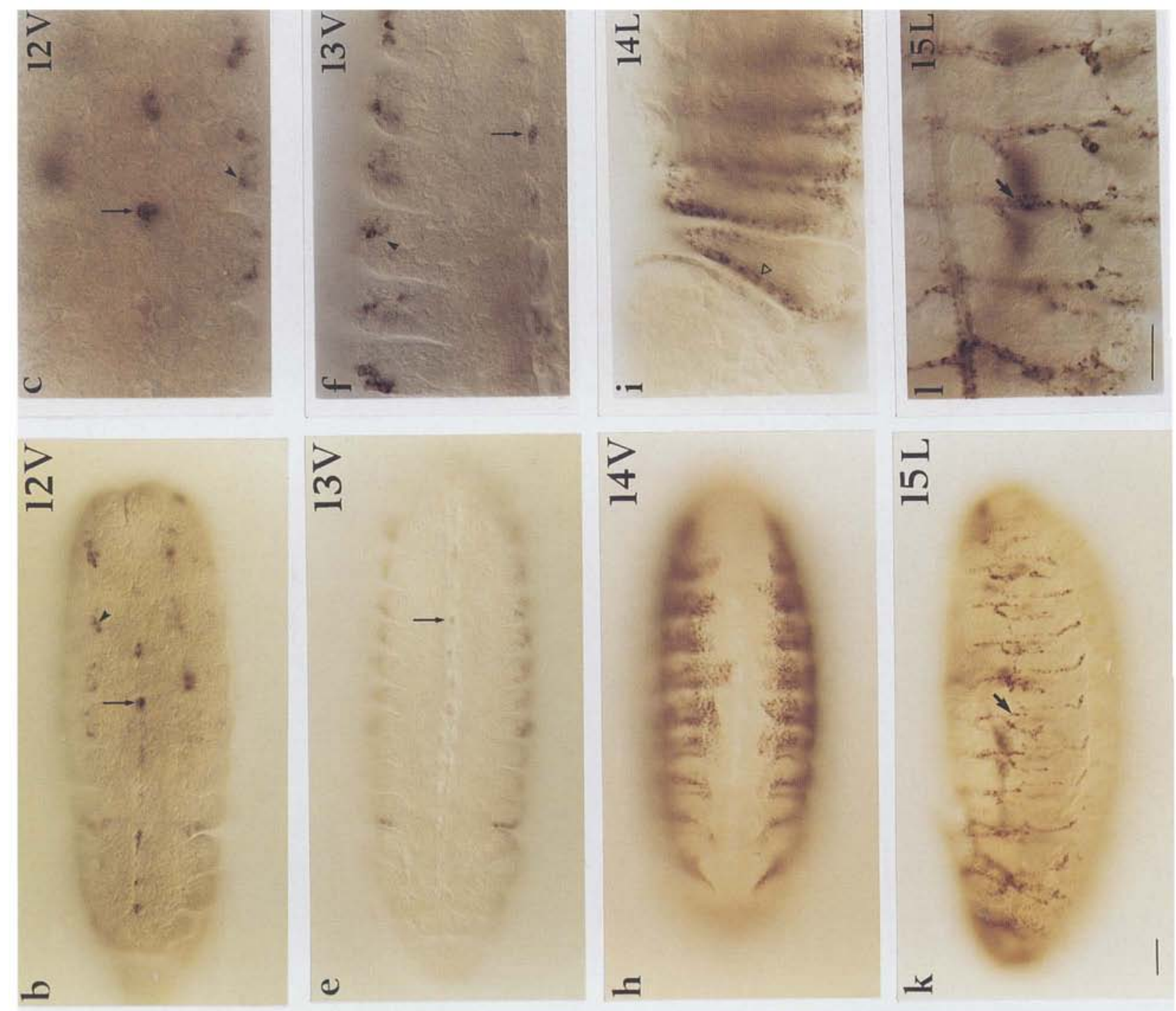

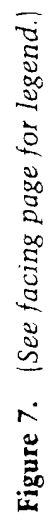
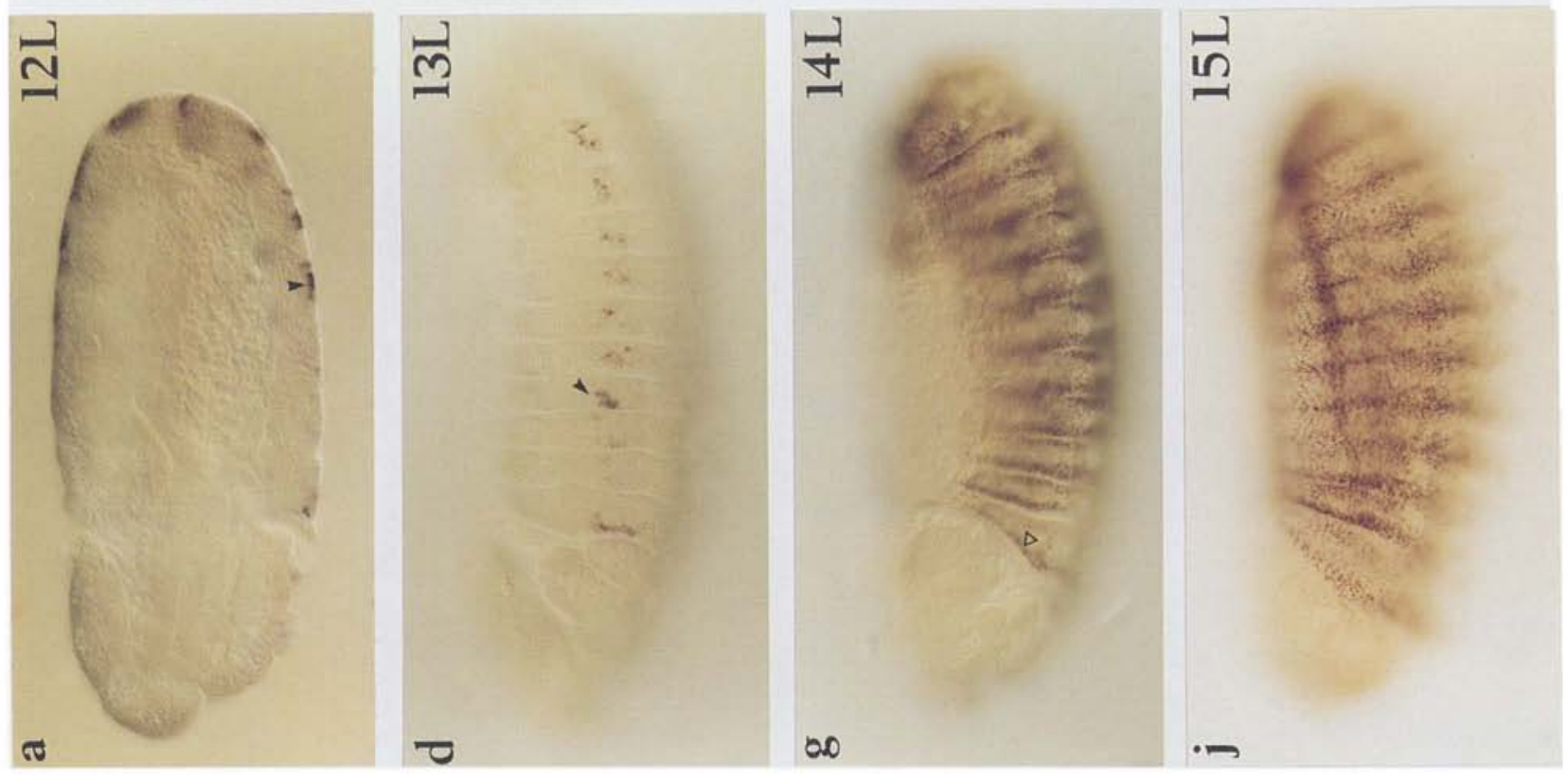
to all somatic muscle attachment sites coincides with the defects observed in the mas mutant animals. Consistent with this notion, the mutant allele mas ${ }^{154}$, which removes only the carboxy-terminal portion of mas, is phenotypically a null allele. Several lines of evidence indicate that the carboxy-terminal polypeptide has an extracellular location. First, the primary sequence of the mas protein as well as in vitro translation results (see next section) suggest that the entire protein is secreted. Second, the localization of the carboxy-terminal protein in the tracheal lumen is clearly extracellular. Third, its localization is not what might have been expected from the mas RNA expression pattern, implying that there must be some mechanism by which the carboxy-terminal polypeptide is able to reach its functional sites. It is possible that the localization of the carboxy-terminal polypeptide is receptor mediated. In contrast to the carboxy-terminal polypeptide, there is no indication that the amino-terminal polypeptide plays any functional role other than to promote the processing and trafficking of the carboxy-terminal modified serine protease domain. Epidermal cells /which accumulate the amino-terminal polypeptide) do not appear to be affected in mutants that remove the entire mas coding region.

\section{Implications of the structural features of mas}

As one might expect from the mas protein localization data, the structural features of the deduced protein suggest that mas is synthesized as a preproprotein; the presence of the amino-terminal signal peptide and the absence of a hydrophobic stretch of sufficient length to traverse the membrane suggest that mas is secreted. Consistent with this scenario, preliminary data indicate that mas is translocated into the membrane fraction and protected from protease cleavage when a T7 RNA polymerase transcribed full-length mas mRNA is translated in vitro in the presence of canine pancreatic microsomes (A. Kornezos, pers. comm.).

Both the processing of the mas protein and its primary structure share several common features with serine proteases. It is processed; however, our Western blot data show that mas is cleaved, not at the expected zymogen activation site between residues 802 and 803 , but nearer the amino terminus (see Fig. $5 \mathrm{a}$ and legend) to generate two polypeptides of $35 \mathrm{kD}$ (amino-terminal) and $77 \mathrm{kD}$ (carboxy-terminal). Like other arthropod serine protease proproteins, for example, Drosophila easter and snake proteins and the proclotting enzyme of Limulus, mas also contains disulfide knotted domains. These are thought to mediate complex formation as a prerequisite to zymogen activation (Smith et al. 1994). It is possible that one of these knots in mas serves in this capacity.

By analogy with serine proteases, the cleavage of mas proprotein facilitates the folding of the mas carboxy-terminal-modified protease domain into its final functional conformation. This domain is located extracellularly and, presumably, can be localized to its site of action by binding to specific receptors. Because the catalytic serine has been replaced by a glycine in mas, it probably cannot act as a protease; however, the high degree of overall conservation with the protease domains of other serine proteases, that is, the cysteine residues involved in forming disulfide bridges and the residues lining the substrate binding pocket, raises the possibility that the mas carboxy-terminal domain can adopt a similar conformation to that of serine proteases.

\section{Possible mechanisms of action of mas}

How does the extracellular carboxy-terminal-modified protease domain of mas act to promote or stabilize cellmatrix interactions? One possibility is that it acts as a novel substrate adhesion molecule/ligand to directly promote or to signal cell-substrate adhesion mechanisms. In this scenario, we propose that the conserved serine protease domain that is normally used to facilitate enzyme-substrate interactions has been adapted (in an enzymatically inactive form/ in mas for a similar role in mediating protein-protein interaction.

This biological strategy appears to have been used in several growth factors and adhesion molecules. The human hepatocyte growth factor (HGF), the Drosophila adhesion molecules glutactin and neurotactin, as well as vertebrate thyroglobulin, are some examples of molecules that show homology to enzymes except that they lack critical catalytic groups. Like mas, HGF is structurally similar to serine proteases but has alterations in 2 of the 3 residues in the catalytic triad (Nakamura et al. 1989|. It has been suggested that the modified protease domain acts as a ligand to activate c-met tyrosine kinase activity (Bottaro et al. 1991). The adhesion molecules glutactin and neurotactin both belong to the family of serine esterases (Barthalay et al. 1990; de la Escalera et al. 1990; Hortsch et al. 1990; Olson et al. 1990). In these proteins the catalytic serine is not conserved, and it is unlikely that the molecules possess esterase activity. The conserved regions may be responsible for the adhesive properties of neurotactin and glutactin. Vertebrate thyroglobulin also contains the defective cholinesterase domain lacking the catalytic serine and may be involved

Figure 7. The mas embryonic RNA expression pattern. Whole-mount embryos were hybridized to digoxygenin-labeled mas cDNA (see Materials and methods). Lateral (L) and ventral (V) views of stage $12(a-c)$, stage $13(d-f)$, stage $14(g-i)$, and stage $15(j-l)$ embryos are shown, with anterior at left. $a, d, g$, and $j$ focus on the progression of epidermal expression of mas; note the stronger expression in cells near the segmental boundaries ( $g$ and $i$, open arrowhead). $b, e$, and $h$ focus on the progression of mas expression in a few cells along the midline of the CNS. mas is expressed in these midline cells during stages 12 and $13(b$ and $e$, fine arrow), but midline expression ends by stage $14(h)$. Higher magnifications of $b$ and $e$ are shown in $c$ and $f$, respectively. $k$ and $l$ focus on the expression seen in the tracheal system (thick arrow); higher magnification of an older stage 15 embryo is shown in $I$. Bars $\langle k, 1\rangle, 25 \mu m$. 
in the dimerization of cholinesterases and thyroglobulin (Mercken et al. 1985).

An alternative mechanism, which is not necessarily excluded and which may work in conjunction with the model proposed previously, is that mas stabilizes adhesive interactions between the cell surface and extracel-
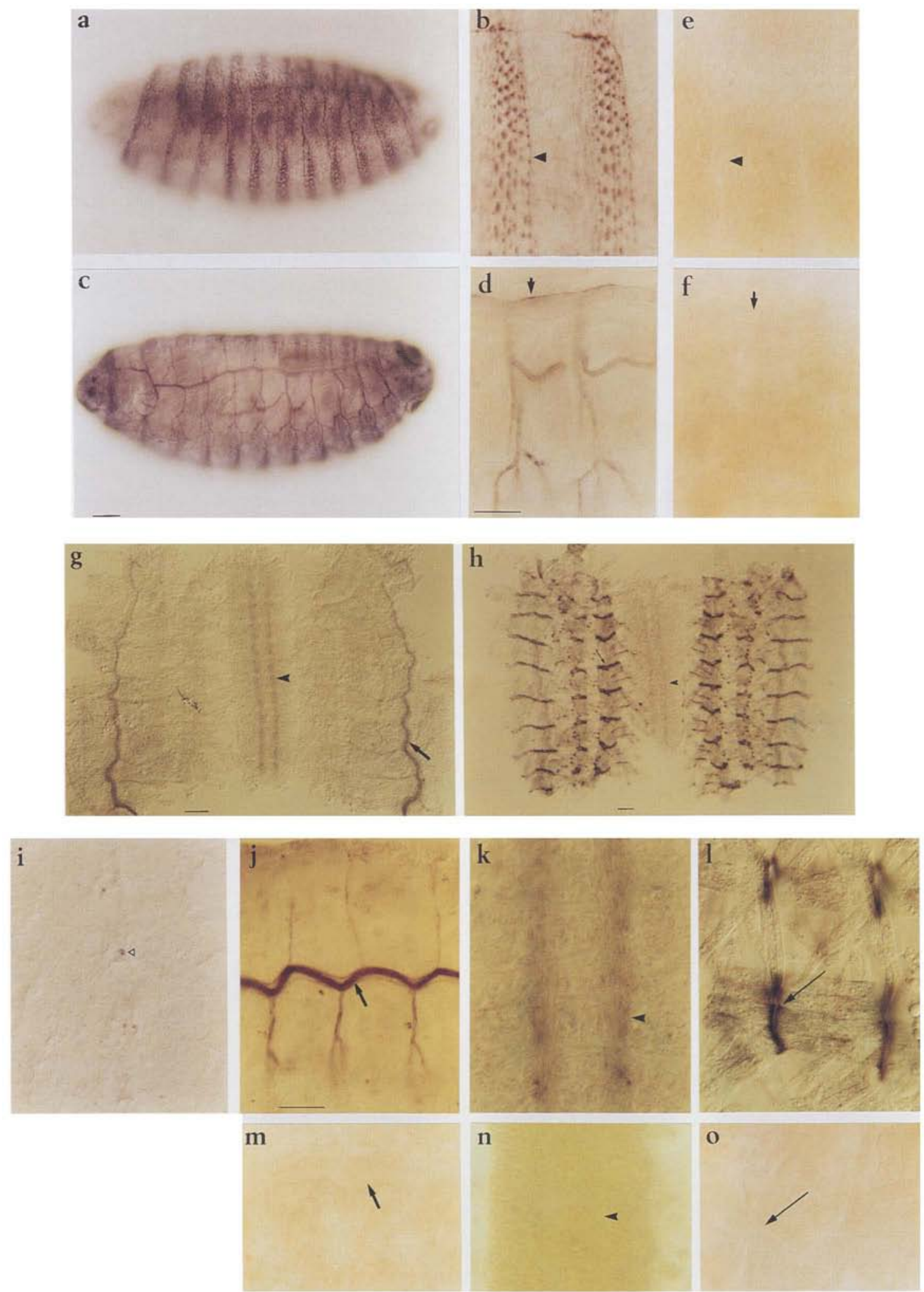

n

o

Figure 8. (See facing page for legend.) 
lular components by acting as a protease antagonist. Given the predicted structural similarities between mas and serine proteases, it is certainly conceivable that the carboxy-terminal domain of mas can compete for the substrates of trypsin-like serine proteases. In this scenario, mas would act to antagonize the activity of serine protease (e.g., molecules like the membrane-associated serine protease encoded by $s b$-sbd), and its absence would result in an excess of protease activity at a specific locale; an imbalance in favor of protease activity can potentially destabilize cell-substrate interaction in at least two different ways. First, destabilization can be caused by the excessive local proteolytic degradation of components of the ECM as well as receptors for matrix molecules on the cell surface (e.g., Monard 1988). A second possible mechanism for destabilization of cell-substrate interaction could be effected by protease-mediated activation of a signal transduction pathway; for example, the activity of the protease thrombin causes the activation of cell surface receptors (Vu et al. 1991), this being the apparent reason why thrombin causes neurite retraction in culture (Suidan et al. 1992).

The issue of mechanism aside, it is interesting to note that the defective muscle attachment seen in mas mutants occurs with incomplete expressivity. We believe that this is a reflection of the fact that many components are involved in effecting muscle attachment; the function of the components overlap, and the loss of some of the components can be compensated by those that remain. There are examples of mutations that abolish substrate and cell adhesion molecule function that do not cause obvious phenotypes as a result of the high degree of redundancy. In this respect, the embryonic defects observed for the mas null alleles are unusual and implicate mas as a functional and limiting extracellular component in the process of muscle attachment.

\section{Materials and methods}

All standard molecular biology procedures were performed according to Sambrook et al. (1989).
Strains

The $\left.\mathrm{P} / \mathrm{w}^{+} \mathrm{ry}^{+}\right] 64 \mathrm{~B}$ insertion strain was kindly provided by Bob Levis (Levis et al. 1985). The original strain contained an unlinked lethal that was recombined out by constructing a homozygous $\left.w_{;} P / w^{+} r y^{+}\right] 64 B h$ th $c u$ sr $e$ strain. This strain was used in all subsequent experiments. The $M h c-l a c Z$ transformant line was a gift from S. Bernstein (Hess et al. 1989). Details of balancer and marker strains are listed in Lindsley and Zimm (1992).

Isolation of mas genomic DNAs and cDNAs

An EMBL4 genomic library of Sall fragments was prepared from the mas P-element insertion line. Clones containing DNA flanking the $P$ element were isolated using the $5^{\prime}$ end of the $\mathrm{P}$ element as a probe. The flanking DNA was used to screen a wild-type genomic EMBL3 library (Tamkun et al. 1992), and $\sim 20 \mathrm{~kb}$ of DNA encompassing the insertion site was isolated and restriction mapped. The wild-type genomic clones were used as probes for Northern blots and to screen embryonic cDNA libraries (Poole et al. 1985; Brown and Kafatos 1988).

\section{Northern blot analysis}

Poly $(\mathrm{A})^{+}$RNA was prepared using standard methods. Two micrograms of poly $|\mathrm{A}\rangle^{+}$RNA from each developmental stage were separated on formaldehyde/agarose gels, transferred to nylon membranes, hybridized, and exposed as described in Sambrook et al. (1989).

\section{DNA sequencing}

The cDNA was subcloned into Bluescript $|+|$ |Stratagene $\mid$, and nested deletions were prepared by the exonuclease III Erase-abase system (Promega). Both strands of the cDNA were sequenced by the dideoxy chain-termination method with Sequenase (U.S. Biochemical). Genomic DNA was sequenced using oligonucleotide primers based on the cDNA sequence. Protein homology searches were carried out using the data bases at the National Center of Biotechnology Information, National Institutes of Health $(\mathrm{NIH})$ with the suite of BLAST programs.

\section{Whole-mount embryo RNA in situ hybridizations}

Staging of the embryos was according to Campos-Ortega and Hartenstein (1985). Localization of RNA in whole-mount em-

Figure 8. The differential localizations of the carboxy-and amino-terminal portions of the mas protein. $(a-d)$ Stage 16 embryo whole mounts stained with an antibody directed against a peptide corresponding to an amino-terminal region of mas (see Fig. $5 \mathrm{a}$ ), viewed at different focal planes; anterior is at left and dorsal is on top. $\{a\}$ Staining is seen in the epidermis in a pattern that corresponds with the denticle belts (for higher magnification, see $b$, arrowhead). (c) Staining can be seen in the tracheal system primarily along the lumenal surface (for higher magnification, see $d$, short arrow). (e,f) Stage 16 mas null embryo whole mounts double-stained with antibody against the amino-terminal mas peptide and anti- $\beta$-galactosidase antibody. Epidermal $(e$, arrowhead $)$ and tracheal $(f$, short arrow) staining are absent in the mas null embryos. $(g-1)$ Filleted embryos stained with antifusion protein antibody directed against the carboxy-terminal modified serine protease domain of mas (see Fig. 5a). (g) Flattened preparation of a stage 15 embryo opened along the dorsal midline; accumulation of the carboxy-terminal portion of the mas protein can be seen in the tracheal lumen (thick arrow) [higher magnification of the tracheal protein localization is shown in $i$ (thick arrow)] and along the axons (solid arrowhead) of the longitudinal connectives [higher magnification shown in $k$ (solid arrowhead)]. (h) A stage 16 embryo opened along the dorsal midline; note the high levels of staining seen at all somatic muscle attachment sites (fine arrow) that were not present at stage 15 (higher magnification of the lateral and ventral muscle attachment site staining is shown in 1 , long arrow); the axons of the longitudinal connectives (arrowhead) and the tracheal lumen (below the plane of focus) are stained. (i) Dorsal view of a dissected stage 13 embryonic CNS; staining can be seen in some unidentified midline cells in the CNS (open arrowhead). (m-o) Stage 16 mas null embryo whole mounts double-stained with anti-fusion protein antibody and anti- $\beta$-galactosidase antibody. $(m)$ High magnification of the tracheal lumen (thick arrow) shows no staining with anti-fusion protein antibody. $(n)$ The axons of the longitudinal connective of the CNS (arrowhead) showing the absence of the carboxy-terminal portion of mas. (o) The attachment sites of the lateral and ventral muscles show no accumulation of mas carboxy-terminal protein (long arrow). Bars $(c, d, g, h, j), 25 \mu \mathrm{m}$. 
bryos was performed essentially as described by Tautz and Pfeifle (1989) with a modification (Yang et al. 1991), using randomprimed, digoxygenin-labeled cDNA probes (Boehringer Mannheim). Antidigoxygenin-HRP (horse radish peroxidase) antibody was used to detect the hybridized probe. Development was with $0.25 \mathrm{mg} / \mathrm{ml}$ of diaminobenzidine, $2 \mathrm{mg} / \mathrm{ml}$ of $D$-glucose and $4 \mathrm{ng} / \mathrm{ml}$ of glucose oxidase as described (Hsu et al. 1988).

\section{Generation of mas alleles by P-element mobilization}

To generate mutations in mas, the P-element inserted $3^{\prime}$ of mas was mobilized, as described previously (Robertson et al. 1988), to try and generate transpositions and imprecise excisions that affect the mas-coding region. Females homozygous for the P-element insertions were crossed to males carrying the $S b \mathrm{P}[\Delta 2$ 3] (99B) element. Progeny jump-starter males containing the $P$ element over $S b \mathrm{P}[\Delta 2-3](99 \mathrm{~B})$ were mated to $w / w ; T M 3$ Ser/ $T M 6 T b$ females. From each of 250 independent crosses set up using single jump-starter males, individual balanced lines were established from one $\mathrm{Sb}^{+}$white-eyed male (representing an excision chromosome) and two $\mathrm{Sb}^{+}$red-eyed males (representing unselected chromosomes that still retain $\left.w^{+}\right)$. Altogether, lines representing 250 independent excision chromosomes and 500 unselected $w^{+}$chromosomes were established. These lines were analyzed by Southern blotting and PCR. $\operatorname{mas}^{x .576}$ was one of the excision chromosomes; mas ${ }^{154}$ represents one of the unselected chromosomes.

Our analysis indicated that two of the lines carrying unselected $w^{+}$chromosomes appear to have resulted from duplicative transposition events with $\mathrm{P}$ elements flanking the mas transcription unit. For one of these double P-element insertion lines, we looked for the simultaneous excision of both elements using the strategy described by Cooley et al. (1990). mas $^{\times 124}$ represents one of the chromosomes resulting from such a double excision event.

\section{Generation of antibodies}

For expression of the carboxy-terminal mas fusion protein, the $1.27-\mathrm{kb}$ BamHI-EcoRI fragment from the cDNA clone that includes amino acid residues 736-1047 was cloned into a modified pGEX vector (Guan and Dixon 1991). Using standard protocols, fusion proteins electroeluted from SDS-PAGE gel slices were used to immunize rabbits. The peptide CKKPSTTKKVATAKPKDKEEATKADD, which corresponds to residues 164-188 of mas, was coupled to bovine serum albumin (BSA) via the amino-terminal cysteine, not present in mas, using $m$-maleimidobenzoyl- $N$-hydroxysuccinimide ester (Sigma) (Harlow and Lane 1988). Two-hundred milligrams of the fusion protein and $100 \mathrm{mg}$ of the conjugated peptide were emulsified $1: 1$ with Freund's complete adjuvant (BRL) and injected intradermally into female rabbits. The rabbits were boosted every 3 weeks and bled 10 days later. The peptide antibody was affinity purified using Pierce's Sulfolink coupling gel. The fusion protein antibody was purified using the low-pH method described in Sambrook et al. (1989).

\section{Whole-mount staining of embryos with antibodies}

The whole-mount staining protocol of Mitchison and Sedat (1983) was used with modifications by Gould et al. (1990) and Rob White (pers. comm.). Briefly, embryos were fixed for $40 \mathrm{~min}$ in heptane/paraformaldehyde, devitellinized, and washed extensively in PBS containing $0.1 \%$ Triton X-100 (PTX). They were blocked with $0.1 \%$ BSA in PTX (PBTX) and incubated overnight with primary antibody. Secondary antibodies conju- gated to biotin and the avidin-biotin complex /ABC Kit, Vector $\mathrm{Lab} /$ were used, and the staining was developed as described by Hsu et al. (1988). Unless stated otherwise, mutant alleles were balanced over "blue balancer" chromosomes that carried an insertion containing $U b x-l a c Z$ to facilitate the identification of homozygous mutant embryos. Antibodies directed against bacterial $\beta$-galactosidase were obtained from Sigma, and the antiMHC antibody was a kind gift from Dan Kiehart (Kiehart and Feghali 1986). Activity staining was performed according to Ashburner (1989). Embryos were observed using Nomarski optics and staged according to Campos-Ortega and Hartenstein (1985).

\section{Western blot analysis}

Homogenates were prepared in $2 \times$ SDS gel-loading buffer (Sambrook et al. 1989), with $1 \mathrm{mM}$ PMSF, and electrophoresed on a $10 \%$ SDS-polyacrylamide gel. The transfer to a nitrocellulose filter (Amersham's Hybond-C Extra) was performed using transfer buffer ( $\mathrm{pH}$ 8.3) (Sambrook et al. 1989). The filter was preincubated for $1 \mathrm{hr}$ at room temperature with PBS containing $1 \%$ BSA and $0.1 \%$ Tween 20 . Primary antibody was added to the appropriate dilution followed by an overnight incubation at $4^{\circ} \mathrm{C}$. The filter was washed, incubated with peroxidase-conjugated secondary antibody for $1 \mathrm{hr}$, and, after washing, developed using the BM Chemiluminescence Western blotting reagents (Boehringer Mannheim).

\section{Acknowledgments}

We thank Rohini Balakrishnan for help with the initial behavior screens; Dan Kiehart for the anti-MHC antibody; Tom Kornberg's laboratory and Nick Brown for cDNA libraries and John Tamkun for a genomic EMBL3 library; K. VijayRaghavan, Bor Luen Tang, Alan Porter, Phil Walker, Louis Leong, and Wanjin Hong for discussions and advice; Oon Swee Huat for help with the computer software; Morgan Huse for restriction mapping the mas mutants; Martin Wasser for help with the genomic sequencing; and Y.H. Tan for his continued interest and support. We are grateful to Michael Bate, Nick Harden, David Murphy, Catherine Pallen, Bor Luen Tang, K. VijayRaghavan, and members of our lab for comments on the manuscript. We thank the Institute of Molecular and Cell Biology (IMCB), the European Community, and the Rockefeller Foundation for financial support

The publication costs of this article were defrayed in part by payment of page charges. This article must therefore be hereby marked "advertisement" in accordance with 18 USC section 1734 solely to indicate this fact.

\section{Note added in proof}

The nucleic acid sequence of mas has been to deposited to the GenBank data library under accession number U18130.

\section{References}

Appel, L.F., M. Prout, R. Abu-Shumays, A. Hammonds, J.C. Garbe, D. Fristrom, and J. Fristrom. 1993. The Drosophila stubble-stubbloid gene encodes an apparent transmembrane serine protease required for epithelial morphogenesis. Proc. Natl. Acad. Sci. 90: 4937-4941.

Ashburner, M. 1989. Drosophila: A laboratory manual. Cold Spring Harbor Laboratory Press, Cold Spring Harbor, New York. 
Bard, J. 1990. Morphogenesis: The cellular and molecular processes of developmental anatomy. Developmental and Cell Biology series, pp. 65-117. Cambridge University Press, Cambridge, UK.

Barthalay, Y., R. Hipeau-Jacquotte, S. de la EScalera, F. Jimenez, and M. Poivant. 1990. Drosophila neurotactin mediates heterophilic cell adhesion. EMBO /. 9: 3603-3609.

Bate, M. 1990. The embryonic development of larval muscles in Drosophila. Development 110: 791-804.

- 1993. The mesoderm and its derivatives. In The development of Drosophila melanogaster (ed. M. Bate and A. Martinez Arias), vol. II, pp. 1013-1090. Cold Spring Harbor Laboratory Press, Cold Spring Harbor, New York.

Bogaert, T., N. Brown, and M. Wilcox. 1987. The Drosophila PS2 antigen is an invertebrate integrin that, like the fibronectin receptor, becomes localised to muscle attachments. Cell 51: 929-940.

Bottaro, D.P., J.S. Rubin, D.L. Faletto, A.M. Chan, T.E. Kmiecik, G.F. Vande Woude, and S.A. Aaronson. 1991. Identification of the hepatocyte growth factor receptor as the c-met protooncogene product. Science 251: 802-804.

Brabant, M.C. and D.L. Brower. 1993. PS2 integrin requirements in Drosophila embryo and wing morphogenesis. Dev. Biol. 157: 49-59.

Broadie, K. and M. Bate. 1993. Muscle development is independent of innervation during Drosophila embryogenesis. Development 119: 533-543.

Brower, D.L. and S.M. Jaffe. 1989. Requirement for integrins during Drosophila wing development. Nature 342: 285-287.

Brower, D.L., M. Wilcox, M. Poivant, R.J. Smith, and L.A. Reger. 1984. Related cell surface antigens expressed with positional specificity in Drosophila imaginal discs. Proc. Natl. Acad. Sci. 81: 7485-7489.

Brown, N.H. 1993. Integrins hold Drosophila together. Bioessays 15: $383-390$.

- 1994. Null mutations in the $\alpha$ PS2 and $\beta P S$ integrin subunit genes have distinct phenotypes. Development 120: 1221-1231.

Brown, N.H. and F.C. Kafatos. 1988. Functional Drosophila cDNA libraries from Drosophila embryos. I. Mol. Biol. 203: 425-437.

Brown, N.H., D.L. King, M. Wilcox, and F.C. Kafatos. 1989. Developmentally regulated alternative splicing of Drosophila integrin PS2 alpha transcripts. Cell 59: 185-195.

Bunch, T.A. and D.L. Brower. 1993. Drosophila cell adhesion molecules. Curr. Top. Dev. Biol. 28: 81-123.

Campos-Ortega, J.A. and V. Hartenstein. 1985. The embryonic development of Drosophila melanogaster. Springer-Verlag, Berlin, Germany.

Cavener, D.R. 1987. Comparison of the consensus sequence flanking translation start sites in Drosophila and vertebrates. Nucleic Acids Res. 15: 1353-1361.

Chasan, R. and K.V. Anderson. 1989. The role of easter, an apparent serine protease in organising the dorsal-ventral pattern of the Drosophila embryo. Cell 56: 391-400.

Cooley, L., D. Thompson, and A.C. Spradling. 1990. Constructing deletions with defined endpoints in Drosophila. Proc. Natl. Acad. Sci. 87: 3170-3173.

de la EScalera, S., E. Bockamp, F. Moya, M. Poivant, and F. Jimenez. 1990. Characterisation and gene cloning of neurotactin, a Drosophila transmembrane protein related to cholinesterases. EMBO I. 9: 3593-3601.

DeLotto, R. and P. Spierer. 1986. A gene required for the specification of dorsal-ventral pattern in Drosophila appears to encode a serine protease. Nature 323: 688-692.

Dihanich, M., M. Kaser, E. Reinhard, D. Cunningham, and D.
Monard. 1991. Prothrombin mRNA is expressed by cells of the nervous system. Neuron 6: 575-581.

Fessler, J.H. and L.I. Fessler. 1989. Drosophila extracellular matrix. Annu. Rev. Cell Biol. 5: 309-339.

Garrison, K., A.J. MacKrell, and J.H. Fessler. 1991. Drosophila laminin A chain sequence, interspecies comparison, and domain structure of a major carboxyl portion. I. Biol. Chem. 266: 22899-22904.

Gay, N.J. and F.J. Keith. 1992. Regulation of translation and proteolysis during the development of embryonic dorso-ventral polarity in Drosophila: Homology of easter proteinase with Limulus proclotting enzyme and translation activation of Toll receptor synthesis. Biochim. Biophys. Acta 1132: 290-296.

Gloor, S., K. Odink, J. Guenther, H. Nick, and D. Monard. 1986. A glia-derived neurite promoting factor with protease inhibitory activity belongs to the protease nexins. Cell 47:687693.

Goodman, C.S. and C.Q. Doe. 1993. Embryonic development of the Drosophila central nervous system. In The development of Drosophila melanogaster (ed. M. Bate and A. Martinez Arias), vol. II, pp. 1131-1206. Cold Spring Harbor Laboratory Press, Cold Spring Harbor, New York.

Gould, A.P., R.Y.K. Lai, M.J. Green, and R.A.H. White. 1990. Blocking cell division does not remove the requirement for Polycomb function in Drosophila embryogenesis. Development 110: 1319-1325.

Guan, K. and J.E. Dixon. 1991. Eukaryotic proteins expressed in E. coli: An improved thrombin cleavage and purification procedure for fusion proteins with glutathione S-transferase. Anal. Biochem. 192: 262-267.

Gurwitz, D. and D.D. Cunningham. 1988. Thrombin modulates and reverses neuroblastoma neurite outgrowth. Proc. Natl. Acad. Sci. 85: 3440-3444.

Harlow, E. and D. Lane. 1988. Antibodies: A laboratory manual . Cold Spring Harbor Laboratory Press, Cold Spring Harbor, New York.

Hecht, P.M.and K.V. Anderson. 1992. Extracellular proteases and embryonic pattern formation. Trends Cell Biol. 2: 197202.

Henchcliffe, C., L. Garcia-Alonso, J. Tang, and C.S. Goodman. 1993. Genetic analysis of laminin A reveals diverse functions during morphogenesis in Drosophila. Development 118: 325-337.

Hermodson, M.A., L.H. Ericsson, H. Neurath, and K.A. Walsh. 1973. Determination of the amino acid sequence of porcine trypsin by sequenatar analysis. Biochemistry 12: 3146-3153.

Hess, N., W.A. Kronert, and S.I. Bernstein. 1989. Transcriptional and post-transcriptional regulation of Drosophila myosin heavy chain gene expression. In Cellular and molecular biology of muscle development led. L. Kedes and F. Stockdale), pp. 621-631. Alan R. Liss, New York.

Hortsch, M. and C.S. Goodman. 1991. Cell and substrate adhesion molecules in Drosophila. Annu. Rev. Cell Biol. 7: 505557.

Hortsch, M., N.H. Patel, A.J. Bieber, Z.R. Traquina, and C.S. Goodman. 1990. Drosophila neurotactin, a surface glycoprotein with homology to serine esterases, is dynamically expressed during embryogenesis. Development 110: 13271340.

Hsu, S., G. Ju, and L. Fan. 1988. The glucose oxidase-DABnickel method in peroxidase histochemistry of the nervous system. Neurosci. Lett. 85: 169-171.

Hynes, R.O. 1992. Integrins: Versatility, modulation, and signalling in cell adhesion. Cell 69: 11-25.

Jalink, K. and W.H. Moolenaar. 1992. Thrombin Receptor acti- 
vation causes rapid neural cell rounding and neurite retraction independent of classic second messengers. J. Cell Biol. 118: $411-419$.

Kiehart, D.P. and R. Feghali. 1986. Cytoplasmic myosin from Drosophila melanogaster. J. Cell Biol. 103: 1517-1525.

Kreis, T. and R. Vale. 1993. Guidebook to the extracellular matrix and adhesion proteins. Oxford University Press, Oxford, UK.

Kusche-Gullberg, M., K. Garrison, A.J. Mackrell, L.I. Fessler, and J.H. Fessler. 1992. Laminin A chain: Expression during Drosophila development and genomic sequence. EMBO $\mathrm{I}$. 11: 4519-4527.

Lai-Fook, I. 1967. The structure of developing muscle insertions in insects. J. Morphol. 123: 503-528.

Leptin, M., R. Aebersold, and M. Wilcox. 1987. Drosophila position-specific antigens resemble the vertebrate fibronectinreceptor family. $E M B O$ I. 6: 1037-1043.

Leptin, M., T. Bogaert, R. Lehmann, and M. Wilcox. 1989. The function of PS integrins during Drosophila embryogenesis Cell 56: 401-408.

Levis, R., T. Hazelrigg, and G.M. Rubin. 1985. Separable cisacting control elements for expression of the white gene of Drosophila. EMBO I. 4: 3489-3499.

Lindsley, D.L. and G.G. Zimm. 1992. The genome of Drosophila melanogaster. Academic Press, San Diego, CA.

MacKrell, A.J., B. Blumberg, S.R. Haynes, and J.H. Fessler. 1988. The lethal myospheroid gene of Drosophila encodes a membrane protein homologous to vertebrate integrin $\beta$ subunits. Proc. Natl. Acad. Sci. 85: 2633-2637.

Mercken, L., M.J. Simons, S. Swillens, M. Massaer, and G. Vassart. 1985. Primary structure of bovine thyroglobulin deduced from the sequence of its 8,431-base complementary DNA. Nature 316: 647-651.

Mitchison, T.J. and J. Sedat. 1983. Localization of antigenic determinants in whole Drosophila embryos. Dev. Biol. 99: 261-264.

Monard, D. 1988. Cell-derived proteases and protease inhibitors as regulators of neurite outgrowth. Trends Neurosci. 11: $541-544$.

Muta, T., R. Hashimoto, T. Miyata, H. Nishimura, Y. Toh, and S. Iwanaga. 1990. Proclotting enzyme from Horseshoe crab hemocytes, cDNA cloning, disulfide locations, and subcellular localisation. I. Biol. Chem. 265: 22426-22433.

Nakamura, T., T. Nishizawa, M. Hagiya, T. Seki, M. Shimonishi, A. Sugimura, K. Tashiro, and S. Shimizu. 1989. Molecular cloning and expression of human hepatocyte growth factor. Nature 342: 440-443.

Newman, S.M. and T.R.F. Wright. 1981. A histological and ultrastructural analysis of developmental defects produced by the mutation, lethal(1)myospheroid, in Drosophila melanogaster. Dev. Biol. 86: 393-402.

Olson, P.F., L.I. Fessler, R.E. Nelson, R.E. Sterne, A.G. Campbell, and J.H. Fessler. 1990. Glutactin, a novel Drosophila basement membrane-related glycoprotein with sequence similarity to serine esterases. EMBO I. 9: 1219-1227.

Pollanen, J., K. Hedman, L.S. Nielsen, K. Dano, and A. Vaheri. 1988. Ultrastructural localisation of plasma membrane-associated urokinase-type plasminogen activator at focal contacts. J. Cell Biol. 106: 87-95.

Poodry, C.A. 1980. Epidermis: Morphology and development. In The genetics and biology of Drosophila (ed. M. Ashburner and T.R.F. Wright), vol. 2, pp. 443-498. Academic Press, New York.

Poole, S.J., L.M. Kauvar, B. Drees, and T. Kornberg. 1985. The engrailed locus of Drosophila: Structural analysis of an embryonic transcript. Cell 40: 37-43.
Reinhard, E., R. Meier, W. Halfter, G. Rovelli, and D. Monard. 1988. Detection of glia-derived nexin in the olfactory system of the rat. Neuron 1: 387-394.

Robertson, H.M., C.R. Preston, R.W. Phillips, D. JohnsonSchlitz, W.K. Benz, and W.R. Engels. 1988. A stable genomic source of P-element transposase in Drosophila melanogaster. Genetics 119: 75-83.

Sambrook, J., E.F. Frisch, and T. Maniatis. 1989. Molecular cloning: A laboratory manual. Cold Spring Harbor Press, Cold Spring Harbor, New York.

Smillie, L.B. and B.S. Hartley. 1966. Location of disulphide bridges by diagonal paper electrophoresis: The disulphide bridges of chymotrypsinogen A. Biochem. J. 101: 214-228.

Smith, C., H. Giordano, and R. DeLotto. 1994. Mutational analysis of the Drosophila snake protease: An essential role for domains within the proenzyme polypeptide chain. Genetics 136: 1355-1365.

Suidan, H.S., S.R. Stone, B.A. Hemmings, and D. Monard. 1992. Thrombin causes neurite retraction in neuronal cells through activation of cell surface receptors. Neuron 8: 363375.

Sumi, Y., M. Dent, D. Owen, P. Seeley, and R. Morris. 1992. The expression of tissue and urokinase-type plasminogen activators in neural development suggests different modes of proteolytic involvement in neuronal growth. Development 116: 625-637.

Tamkun, J., R. Deuring, M. Scott, M. Kissinger, A. Pattatucci, T. Kaufman, and J. Kennison. 1992. brahma: A regulator of Drosophila homeotic genes structurally related to the yeast transcriptional activator SNF2/SW 12. Cell 68: 561-572.

Tautz, D. and C. Pfeifle. 1989. A non-radioactive in situ hybridisation method for the localisation of specific RNAs in Drosophila embryos reveals translational control of the segmentation gene hunchback. Chromosoma 98: 81-85.

Tomlinson, J.E., J.W. Mclean, and R.W. Lawn. 1989. Rhesus monkey apolipoprotein (a). Sequence, evolution, and sites of synthesis. I. Biol. Chem. 264: 5957-5965.

von Heijne, G. 1985. Signal sequences: The limits of variation. 1. Mol. Biol. 184: 99-105.

1986. A new method for predicting signal sequence cleavage sites. Nucleic Acids Res. 14: 4683-4690.

Vu, T.-K.H., D.T. Hung, V.I. Wheaton, and S.R. Coughlin. 1991. Molecular cloning of a functional thrombin receptor reveals a novel proteolytic mechanism of receptor activation. Cell 64: $1057-1068$.

Werb, Z., P.M. Tremble, O. Behrendtsen, E. Crowley, and C.H. Damsky. 1989. Signal transduction through the fibronectin receptor induces collagenase and stromelysin gene expression. I. Cell Biol. 109: 877-889.

Wilcox, M., D.L. Brower, and R.J. Smith. 1981. A position specific cell surface antigen in the Drosophila wing imaginal disc. Cell 25: 159-164.

Wilcox, M., A. DiAntonio, and M. Leptin. 1989. The function of PS integrins in Drosophila wing morphogenesis. Development 107: 891-897.

Williams, G. and S. Caveney. 1980. Changing muscle patterns in a segmental epidermal field. I. Embryol. Exp. Morphol. 58: $35-61$.

Yang, X., K. Seow, S. Bahri, S. Oon, and W. Chia. 1991. Two Drosophila receptor-like tyrosine phosphatase genes are ex pressed in a subset of developing axons and pioneer neurons in the embryonic CNS. Cell 67: 661-673. 


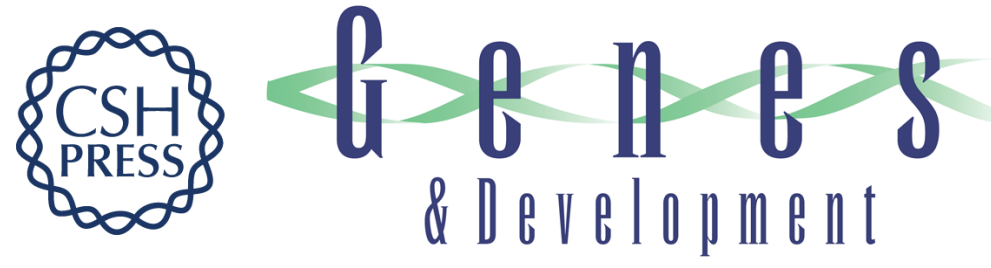

\section{Masquerade: a novel secreted serine protease-like molecule is required for somatic muscle attachment in the Drosophila embryo.}

B Murugasu-Oei, V Rodrigues, X Yang, et al.

Genes Dev. 1995, 9:

Access the most recent version at doi:10.1101/gad.9.2.139

References This article cites 68 articles, 24 of which can be accessed free at:

http://genesdev.cshlp.org/content/9/2/139.full.html\#ref-list-1

License

Email Alerting

Service

Receive free email alerts when new articles cite this article - sign up in the box at the top right corner of the article or click here.

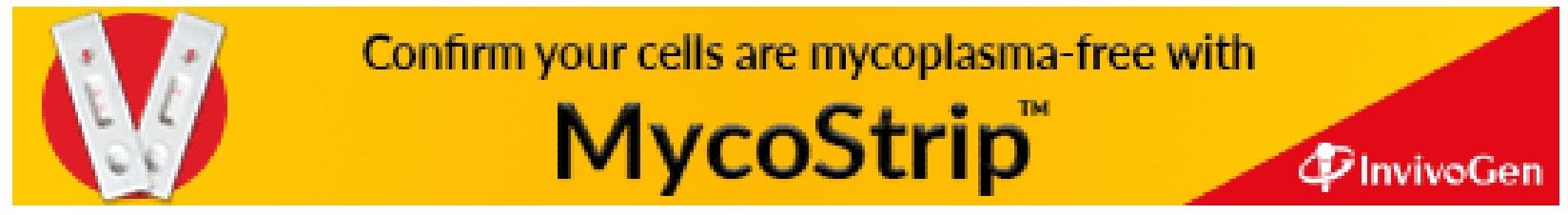

